\title{
Article
}

\section{EU accession from within? An introduction}

Athanassiou, Phoebus and Laulhe-Shaelou, Stephanie

Available at http://clok.uclan.ac.uk/13110/

Athanassiou, Phoebus and Laulhe-Shaelou, Stephanie ORCID: 0000-00023221-5116 (2014) EU accession from within? An introduction. Yearbook of European Law, 33 (1). pp. 335-384. ISSN 0263-3264

It is advisable to refer to the publisher's version if you intend to cite from the work. http://dx.doi.org/10.1093/yel/yeu002

For more information about UCLan's research in this area go to http://www.uclan.ac.uk/researchgroups/ and search for < name of research Group>.

For information about Research generally at UCLan please go to http://www.uclan.ac.uk/research/

All outputs in CLoK are protected by Intellectual Property Rights law, including Copyright law. Copyright, IPR and Moral Rights for the works on this site are retained by the individual authors and/or other copyright owners. Terms and conditions for use of this material are defined in the policies page.

\section{CLoK}

Central Lancashire online Knowledge www.clok.uclan.ac.uk

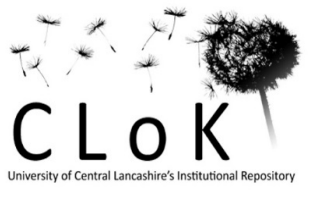




\title{
EU Accession from Within?-An Introduction
}

\author{
Phoebus Athanassiou and Stéphanie Laulhé Shaelou*
}

\section{Introduction}

The entry into force of the Treaty of Lisbon ${ }^{1}$ has seen Member States acquire the formal right to withdraw from the European Union (EU), following the procedure outlined in new Article 50 of the Treaty on European Union (TEU). ${ }^{2}$ Whilst Public International Law (PIL) already recognized the existence of a sovereign right to withdraw from consensual commitments, ${ }^{3}$ including unilaterally, ${ }^{4}$ it was at best questionable whether Member States could have availed themselves of a right to withdraw from the $\mathrm{EU}$ prior to the advent of the Treaty of Lisbon, especially if purporting to claim a right of

* The authors are, respectively, Senior Legal Counsel, European Central Bank, Frankfurt am Main, Germany, E-mail: phoebus.athanassiou@ecb.int and Assistant Professor, Law School, UCLan Cyprus. E-mail: SLaulhe-Shaelou@uclan.ac.uk. The views expressed in this paper are solely those of the authors, and do not necessarily reflect the views of their respective institutions.

1 OJ C 306, 17 December 2007.

${ }^{2}$ An in-depth examination of Art. 50 TEU lies outside the scope of this paper. For an account of Art. 50 TEU see P Athanassiou, 'Withdrawal and Expulsion from the EU and EMU, some reflections' Legal Working Paper Series No 10, ECB, 2009; H Hofmeister, " "Should I stay or should I go?"-A Critical Analysis of the Right to Withdraw from the EU' (2010) 16(5) European Law Journal 589; A Lazowski, 'Withdrawal from the EU and Alternatives to Membership' (2012) 37(5) EL Rev 523; A Tatham, " "Don't mention divorce at the wedding, darling!": EU Accession and Withdrawal after Lisbon' in A Biondi et al (eds) EU Law after Lisbon (OUP, Oxford 2012); and P Nicolaides, 'Withdrawal from the European Union: A Typology of Effects' (2013) 20 (2, Maastricht Journal of European and Comparative Law 209. For pre-Lisbon Treaty works, see $\mathrm{H}$ de Waele, 'The EU on the Road to a New Legal Order-The Changing Legality of Member State Withdrawal' (2004-05) 12 Tilburg Foreign Law Review 168; R Friel, 'Providing a Constitutional Framework for Withdrawal from the EU: Art. 59 of the draft European Constitution' (2004) ICLJ 407, 414 and fn 34; and J Herbst, 'Observations on the Right to Withdraw from the EU: Who are the "Masters of the Treaties”?' (2005) 6 German Law Journal 1755.

3 Under PIL, a right of withdrawal may exist either because the parties to a treaty mutually agree that withdrawal is permissible, whether at the time of the treaty's drafting or expost (see Art. 54 of the 1969 Vienna Convention on the Law of Treaties, UN Treaty Series, vol. 1155, 331) or because it is possible to read a right of withdrawal into a treaty, whether by interpreting the parties' intentions or because such a right would be consistent with the nature of the treaty itself (ibid Art. 56).

${ }^{4}$ Under PIL, unilateral withdrawal is possible under the rebus sic standibus ('fundamental change of circumstances') clause of Art. 62 of the 1969 Vienna Convention on the Law of Treaties. On the relevance of Art. 62 in the EU context, see J Hill, 'The EEC: The Right of Member State Withdrawal' (1982) 12 Georgia Journal of International and Comparative Law 335; S. Berglund, 'Prison or Voluntary Cooperation? The Possibility of Withdrawal from the EU' (2006) 29 Scandinavian Political Studies 147; and Athanassiou (n 2) 12-18. 
unilateral withdrawal. ${ }^{5}$ The perpetual nature of the Treaties, ${ }^{6}$ the on-going process of ever-closer European integration, and the judicially declared irrevocability of the transfer of sovereignty from the Member States to the EU ${ }^{7}$ gave rise to warranted doubts, prior to the advent of the Treaty of Lisbon, as to the existence of any Member State right to withdraw from the EU. ${ }^{8}$ Post-Treaty of Lisbon, not only has the Member States' right to withdraw from the EU been formally recognized but, what is more, there are already intimations that this newly attributed right could be exercised in the foreseeable future. ${ }^{9}$

Apart from a raising a number of questions with regard to its actual scope and the concrete consequences of its exercise, ${ }^{10}$ the recognition of the Member States' right to withdraw is apt to open-up new lines of enquiry relevant to other distinct scenarios with no less of an impact on the EU's composition. One such scenario is that of the non-consensual separation ('secession') of part of the territory of an EU Member State, motivated by a desire for national independence. 'Secession' is, of course, not the same as 'withdrawal', within the meaning of Article 50 TEU, which only contemplates the wholesale departure of a Member State from the EU. It is, however, a germane concept: if EU law allows Member States to withdraw from the EU in toto, what would it have to say about the legal consequences of the separation from a Member State of part of its territory? In particular, would EU law recognize an automatic right of accession to the EU for the benefit of newly created ('seceding') state entities (leading, per force, to an 'internal enlargement' of the EU) or would it resist any attempt at 'accession from within', unless and until the normal accession

\footnotetext{
5 The possibility of unilateral denunciation of EU membership has been envisaged by national courts in several jurisdictions, including the UK (McCarthys Ltd $v$ Smith [1979] 3 All ER 325), France (Administration des Douanes v Société Cafés Jacque Vabre \& J Weigel et Cie SARL [1975] 2 CMLR 336) and Germany (Maastricht Urteil [BVerfGE 89, 155 vom 12 Oktober 1993]; Lisbon Urteil [BVerfG, 2 BvE 2/08 vom 30 June 2009]). The negotiated departure of Greenland would appear to confirm that unilateral withdrawal was, at least originally, neither intended nor implied under the Treaties (see F Harhoff, 'Greenland's Withdrawal from the EC' [1983] 20 Common Market Law Review 13 , 28-31). It has been argued that, "it was the very fact that Greenland remained a part of Denmark that made it necessary that its withdrawal from the EC be a negotiated one' (M Happold, 'Independence: In or Out of Europe? An Independent Scotland and the EU' [2000] 49 ICLQ 15, 32), meaning that Denmark could have unilaterally denounced Greenland's participation in the Communities if no consent had been reached for its departure.

6 See Art. 53 TEU.

7 See ns 152 and 153.

8 The referendum held in June 1975 over the UK's European future suggests that withdrawal was deemed legally possible in at least one jurisdiction. On the UK referendum of June 1975 see Friel (n 2) 408 and fn 11; and Athanassiou (n 2) 12 and fn 24.

9 Post-Lisbon, Prime Minister Cameron vowed to offer Britons a simple 'in/out' referendum choice provided he won the general elections scheduled for 2015. This followed Prime Minister Cameron's previous call for a referendum on Britain's relationship with the EU, defeated at the House of Commons in October 2011. On the legal regime applicable in the UK following the enactment of the EU Bill 2011, and on the quasi-systematic need to hold a referendum for any Treaty change, see P Craig, 'The European Union Act 2011: Locks, Limits and Legality' (2011) 48 Common Market Law Review 1915.

${ }^{10}$ In this regard see Athanassiou (n 2) 22-31.
} 
procedure of Art. 49 TEU has been complied with? Suffice it to say from the outset that no major EU law legal issues would a priori arise where a newly created state entity would not wish to be part of the EU (nor would there be any basis to invoke, in such a case, the newly introduced withdrawal possibility of Article 50 TEU in order to arrange for the newly created state entity's departure). ${ }^{11}$ It is only where a newly created state entity would evince the desire to 'continue being part of the EU' that the delicate EU legal issue of its right of accession to the EU (automatic or otherwise) would need to be tackled.

The aim of this paper is to examine the EU law-related issues arising from a secession scenario. ${ }^{12}$ To achieve its aim, this paper is divided in two Parts. Part I examines the possibility of an 'internal EU enlargement' (or 'EU accession from within'), with an emphasis on the potential existence of a 'right to automatic accession to the EU' (or, better put, a right of 'retention' of accession to the EU). As will be argued in Part I, there is, as a matter of EU law, no automatic right to EU accession in a genuine secession scenario; it will also be argued that a newly created state entity would not enjoy, as a matter of PIL, any a priori rights of state succession to the rights and obligations of the 'rump' Member State (diminished in territory and population) deriving from the latter's membership of the EU. Therefore, EU membership talks would be mandatory, both in terms of outcome (through compliance with the enlargement process) and in terms of procedure (through compliance with the enlargement criteria), even if an expedited accession process might be conceivable. ${ }^{13}$ Part II of this paper explores the issue of the existence of a 'right to automatic accession to EMU' (the most central but exclusive of all areas of EU integration $)^{14}$ for newly created state entities that were formerly part of a euro area Member State. As will be argued in Part II, newly created state entities resulting from secession from an existing euro area Member State would need to 'join the queue', and fulfil the EMU

${ }^{11}$ See S Peers, 'The Future of EU Treaty Amendments' (2012) 31(1) Yearbook of European Law 1760 .

${ }^{12}$ For instance, in Catalonia the ruling party announced its intention to hold a referendum on Catalan independence if it won the next regional elections, despite the Spanish government's claim that such action would be illegal (see M Happold 'Catalan Independence and the EU', available at $<$ http://www.catdem.org/cat/notices/2012/12/catalan-independence-and-the-european-union7034.php>, last accessed 26 August 2013. For his part, Scottish First Minister Alex Salmond expressed the desire for an independent Scotland 'from within the context of the EU' (see M Weller, 'A Foregone Conclusion?' (2012)NLJ 162(7537), available at <http://www.newlaw journal.co.uk/nlj/content/foregone-conclusion>, last accessed 26 August 2013).

13 The general presumption is that, 'the accession of new Member States to the Community is carried out by means of acts which have the status of primary law and can change pre-existing situations in any area of Community law whatsoever, the maintenance in force of existing Community rules being the course generally followed' (see Joint Cases C-63/90 and 67/90, Portugese Republic and Kingdom of Spain v Council of the EC [1992] ECR I-05073, para. 49). Also see S Laulhé Shaelou, The EU and Cyprus: Principles and Strategies of Full Integration (Brill/Martinus Nijhoff Publishers, Leiden, 2010) 97.

${ }^{14}$ Despite the fact that all of the Treaties' objectives, as set out in Art. 3 TEU, are of prime importance, the establishment of EMU is, arguably, the only Treaty objective in the context of which further admission conditions need to be fulfilled (see para. 4 of Art. 3 TEU). 
accession criteria before adopting the single currency, following the EMU accession procedure prescribed in the Treaty.

Before turning to the substance of the analysis in this paper, it is useful to briefly consider a few points of terminology. A caveat and a word of caution are also apposite.

'Secession' can be defined as the non-consensual (even if not belligerent) separation of part of the territory of an existing state, without such separation resulting in the extinction of the predecessor state. ${ }^{15}$ Examples include the breakup of Belgium from the Netherlands, in 1830, and that of Pakistan from British India, in 1948. The standard, decolonization-era account based claims to the creation of so-called 'newly independent states' ${ }^{16}$ upon the principle of selfdetermination, following which nations and peoples have the inalienable right to determine freely their destiny. ${ }^{17}$ Outside the decolonization context (which is not relevant for the analysis in this paper), it is difficult to argue that there exists an absolute right to secession in cases of grievances internal to a state, since the recognition of any such right would violate the fundamental PIL principle of territorial integrity. ${ }^{18}$ The opposite of secession is 'dissolution', which can be defined as the fragmenting, negotiated or otherwise, of an existing state into two or more new state entities (which may, but need not be, co-terminous with preceding territorial components), resulting in the extinction of the predecessor state. ${ }^{19}$ The dismemberment of the Socialist Federal Republic of Yugoslavia (SFRY), and the demise of Czechoslovakia provide examples of non-consensual (or 'genuine') and negotiated dissolution, respectively. Several other paths to statehood exist, including the 'separation' of a voluntary union of states into its original constituent parts-a reversion, so to speak, to the status quo ante-as in the case of the break-up, in 1961, of the United Arab Republic into the preunion sovereign States of Syria and Egypt or the 'fusion' of two or more states into a new one, as in the case of Germany's re-unification, in $1990 .^{20}$

\footnotetext{
15 Crawford and Boyle have defined secession as 'the process by which a group seeks to separate itself from the state to which it belongs and to create a new state on part of that state's territory' (J Crawford and A Boyle, 'Annex A-Opinion: Referendum on the Independence of ScotlandInternational Law Aspects' in 'Scotland analysis: devolution and the implications of Scottish independence', available at <https://www.gov.uk/government/uploads/system/uploads/attachment_ data/file/79408/Annex_A.pdf>, 12 February 2013, last accessed 26 August 201372.

16 The term applies to states resulting from decolonization, and is defined in the 1978 Vienna Convention as 'a successor State the territory of which immediately before the date of the succession of States was a dependent territory for the international relations of which the predecessor State was responsible' (see Art. 2. f).

17 See, generally, MN Shaw, International Law (6th edn, Cambridge University Press 2008) 251-7; J Combacau and S Sur, Droit international public (5th edn, Montchrestien, Paris 2001) 264; and T Schweisfurth, Völkerrecht (Mohr Siebeck, Tübingen 2006) 328.

18 P Dailler and A Pellet, Droit international public (LGDJ, Paris 2002) 526.

19 Ibid 525-6.

${ }^{20}$ It is equally possible to treat the German re-unification as an example of absorption of one state by another rather than as one of a merger (in this regard, see I Brownlie, Principles of Public
} 
These alternative paths to statehood are not examined below, as they are not relevant to this paper.

The caveat is that it is not the authors' intention to focus on specific cases of potential secession affecting specific EU Member States. Their aim is, instead, to identify common legal issues arising out of secession scenarios that are or could be of relevance to EU Member States in general, without regard to national specificities, legal or other.

Finally, a word of caution: despite the existence of a strong political dimension to the secession debate, the arguments presented in this paper are purely legal. Political or philosophical considerations having an impact (perhaps a decisive one) on the questions examined in this paper will be no part of the authors' analysis. ${ }^{21}$

\section{I. 'Internal EU enlargement?': the EU and PIL perspectives}

Part I examines whether a newly created state entity would automatically be bound by the obligations and enjoy the rights and prerogatives of the EU Member State whose sovereign power it has displaced over part of the latter's territory through the act of secession (including rights and obligations deriving from its membership of the EU). This question is addressed both from the perspective of EU law (section A) and from that of PIL (section B).

\section{A. EU law considerations}

\section{(i) Introductory remarks: the rump Member State's legal position in a genuine secession scenario}

As mentioned earlier in this paper, the Treaty of Lisbon has expressly recognized the Member States' right to withdraw from the EU, following the procedure outlined in new Article 50 TEU. ${ }^{22}$

International Law (7th edn, OUP, Oxford 2008) 964-6; P Malanczuk, Akehurst's Modern Introduction to International Law (Routledge, London/New York 1997) 167-8).

${ }^{21}$ For an example of some of those considerations and an assessment of their possible impact on the secession debate see A Roldan and N Brullet, 'El dilemma del prisoniero catalán' El País, 28 January 2013, 29.

${ }^{22}$ Unlike in the case of EU accession, no criteria apply in the case of withdrawal. Art. 50(1) TEU provides that any Member State may withdraw from the EU in accordance with its own constitutional (ie internal) requirements. Despite being an instance of 'redefinition' of a Member State's territory rather than of state secession, which preceded the introduction by the Treaty of Lisbon of the exit clause, the case of Greenland would appear to be a good illustration of 'internal considerations leading to potential withdrawal' (Tatham (n 2) 148-9). Following the introduction of 'home rule' in 1979 , and the holding of a referendum on membership of the Communities by the Greenlandic government in 1982, the Danish government 'acted upon' the request by the Greenlandic government and requested the Council 'to amend the Treaties in order to allow for the withdrawal of Greenland and its transfer to the status of OCT' (E.C. Bull, Supplement 1/83, 6 (request to the 
Article 50 TEU would, a priori, be irrelevant to the secession scenario that is the focus of this paper, since the Treaty of Lisbon recognizes a right of withdrawal for the benefit of each of the Member States, rather than for the benefit of parts thereof, which, by definition, cannot negotiate their withdrawal from the EU since they have never been EU members in their own right. ${ }^{23}$ At the same time, there is nothing in the Treaties to suggest the existence of any obligation for the rump Member State to withdraw from the $\mathrm{EU}^{24}$ or to otherwise re-negotiate its relationship with its partners merely because of incidents of secession affecting its territory and population. ${ }^{25}$ It is recalled that the territory of Member States is to be determined by reference to national (including Constitutional) law considerations, ${ }^{26}$ rather than by reference to the EU Treaties. ${ }^{27}$ As no Treaty amendments would appear necessary to reflect changes

Council) and $\operatorname{COM}(83) 66$ final (Commission's opinion)). The Danish government entered into negotiations (on behalf of Greenland) with other Member States, to decide on Greenland's withdrawal and on its transformation into an OCT. These negotiations gave rise to an amending Treaty on Greenland ([1985] OJ L29/1) passed on the basis of the now repealed Art. 236 EEC (formal Treaty revision procedure requiring unanimity), which took effect with Greenland's withdrawal on 1 February 1985 (see Tatham (n 2), 146-7; see also S Blockmans, 'Between the Devil and the Deep Blue Sea? Conflicts in External Action Pursued by OCTs and the EU' in D Kochenov (ed.), EU Law of the Overseas: Outermost Regions, Associated Overseas Countries and Territories, Territories Sui Generis (Kluwer Law International, The Netherlands 2011), 312-14; F Weiss, 'Greenland's withdrawal from the European Communities' (1985) 10 European Law Review 173; and Harhoff (n 5) 17-21.

23 See Happold (n 5) 32-3; and 'Scottish nationalists in EU "fantasy land", available at $<$ http://www.publicserviceeurope.com/print-article.asp?id=2845>, last accessed on 26 August 2013. In case of the independence of a seceding entity (rather than of EU withdrawal) it would not be possible for the Council to reflect on the practice of Art. 49 TEU for EU accession and to request, by analogy, opinions and proposals from the other EU institutions, on the eventual withdrawal of the entity seeking independence (see Tatham (n 2) 150 with respect to the procedure for the withdrawal of a Member State). Contra Edward, who has expressed the view that Art. 50 TEU could be extended to cater for the needs of seceding state entities (see Edward, 'Scotland and the European Union', Scottish Constitutional Futures Forum blog, 17 December 2012, available at $<$ http://www. scottishconstitutionalfutures.org/OpinionandAnalysis/ViewBlogPost/tabid/1767/articleType/

ArticleView/articleId/852/David-Edward-Scotland-and-the-European-Union.aspx $>$, accessed on 6 January 2014).

${ }^{24}$ See Crawford and Boyle (n 15) 68 and 99 (arguing that the UK's EU membership would not 'lapse' in the event that Scotland would attain its independence).

${ }^{25}$ For the extent to which such adjustments to the rump Member State would need to be reflected in the EU Treaties, see Lenaerts and Van Nuffel, Constitutional Law of the EU (Thomson/Sweet \& Maxwell 2005) 356.

26 See Case 148/77, Hansen v Hauptzollamt Flensburg [1978] ECR 1787, where the Court ruled with respect to the territorial extent of an EU Member State, as set out in then Art. 227 EEC (now Articles 52 TEU and 355 TFEU), that 'the status of the French overseas departments within the Community is primarily defined by reference to the French constitution...' (para. 10)). Also see Crawford and Boyle (n 15) 101.

27 Post-Lisbon, new Art. 52 (1) TEU merely sets out a list of Member States, while Art. 52(2) TEU refers to Art. 355 TFEU for details of the territorial scope of the Treaties. For its part, Art. 355 TFEU refers to specific territories of the Member States (including by reference to Annex II) and also provides for a 'passerelle' clause for some of these territories (Art. 355(6) TFEU). There is, however, no mention in Article 355 TFEU of the territories of certain Member States (in particular, there is no reference to the possibility for Spanish or British territories to benefit from the passerelle clause). Moreover, the passerelle clause only concerns current Overseas Countries or Territories (OCTs) and Outermost Regions (ORs) and it is therefore 'impossible to employ this procedure to change the 
to a Member State's borders, ${ }^{28}$ it would be open to a Member State 'to change the territorial scope of the Treaties unilaterally', for instance by granting independence to a seceding entity (or, a fortiori, by suffering a reduction in its territory and population on account of a unilateral act of secession). ${ }^{29}$ Besides, there are several examples to date ${ }^{30}$ of variations in respect of the territory, population, or internal structure of specific Member States, which have been addressed without a Member State exit, and without the need to amend the Treaties. ${ }^{31}, 32$ In a genuine secession scenario, within the meaning of this paper, the rump Member State would therefore continue to be bound by the Treaties: ${ }^{33}$ it is only if it were to evince the desire to withdraw, independently of the act of secession affecting it, that it could be absolved of its Treaty

status of a Member State region or territory even if they are referred to in Art. 355(6) TFEU, if such a region or territory does not fall within the two statuses' D Kochenov, 'The EU and the Overseas: Outermost Regions, Overseas Countries and Territories associated with the Union, and Territories sui generis' in D Kochenov (ed.), EU Law of the Overseas: Outermost Regions, Associated Overseas Countries and Territories, Territories Sui Generis (Kluwer Law International, The Netherlands, 2011), 60-3, 62).

28 See also the 'moving treaty boundary' concept in Happold (n 5) 33.

29 See Crawford and Boyle (n 15) 101, with respect to the UK.

30 On changes to the constitutional status of overseas and/or other (semi)-autonomous territories/ dependencies of Member States, and their impact on the EU Treaties, see Kochenov (n 27); and S Laulhé Shaelou, 'The Principle of Territorial Exclusion in the EU: SBAs in Cyprus—a Special Case of sui generis Territories in the EU' in D Kochenov (ed.), EU Law of the Overseas: Outermost Regions, Associated Overseas Countries and Territories, Territories Sui Generis (Kluwer Law International, The Netherlands, 2011). Greenland's departure from the EEC did not affect Denmark's membership, although the territorial scope of application of the Treaties changed as a result. Despite being an autonomous territory since 1979 , Greenland remains part of Denmark and has yet to gain independence (see Blockmans (n 22) 312-14; and Crawford and Boyle (n 15) 99).

31 The German reunification provides a case in point, as no specific amendment was made to the EC Treaties to reflect the increase in the Federal Republic of Germany's territory and population (see J-P Jaqué, 'German Unification and the EC' (1991) 2 European Journal of International Law, 1).

32 Variations in a Member State's territory and population may, depending on their nature and scope, have an impact on a Member State's representation and voting rights (see Crawford and Boyle (n 15), 100; and Happold (n 5) 20)). With respect to voting rights and the rules on Member States' representation at the EU institutions, these may be contained in secondary legislation, as in the case of the European Parliament (Art. 14(2) TEU). Acts of secondary legislation, by their very nature, can be amended without recourse to primary law, unless they are themselves the result of a Treaty amendment (as in the case of Greenland's withdrawal, which entailed changes to secondary legislation) or, by way of exception, in the context of EU accession (under the conditions of admission as set out in Art. 49 TEU and interpreted by the Court of Justice) (see Peers (2012), 19 and 27; see also Laulhé Shaelou (2010) 96-98). In the case of the Council, the main rules on voting weights are based on population and, as of 2014, automatically take into consideration a drop in population of a Member State (see Art. 16(4) TEU; and Peers (n 11) 61 and fn 257). In theory, any other hypothetical change to primary law outside of the scope of the EU accession process would need to be addressed through one of the revision procedures (ie under Art. $48 \mathrm{TEU}$ and/or possibly under one of the passerelle clauses of the Treaties, if relevant). It is logical to assume that any Treaty changes made on the basis of Art. 48 TEU would be addressed, probably, at the same time as the new state entity's Accession Treaty, to avoid a multiplication of Treaty revision processes.

33 Contra Matas et al who argue that both the successor State(s) and the predecessor State (if still existing) would be responsible ‘jointly and severally' for the Treaty obligations of the Member State from which they have resulted (see Jordi Matas i Dalmases et al, 'The Internal Enlargement of the EU', Centre Maurits Coppieters, 2010, 69. 
obligations, subject to fulfilment of the procedural requirements laid down in Article 50 TEU.

In light of the above, the EU law position of the rump Member State in a genuine secession scenario is, in the authors' opinion, clear: the rump Member State would carry forward its legal personality and continue to enjoy its EU membership rights and obligations notwithstanding secession, without the changes to its territory resulting from secession raising particular concerns as a matter of primary EU law. What the position of the newly created state entity would be is, however, a different matter. Can the newly created state entity claim an automatic right of (re)accession to the EU, or would it need to follow the regular accession procedure before acceding to the EU? These questions are addressed in subsection (ii).

\section{(ii) Automatic EU (re-)accession?}

Outside Article $49 \mathrm{TEU}$, there is no dedicated Treaty provision specifically on the situation of newly created state entities and/or on their EU accession (or (re-)accession) rights. Nor, as explained below, is there any reason, either in logic or in law, why there should be any such provision.

The general principles of EU law, including those of equal treatment, legal certainty, and legitimate expectations, require that the enlargement conditions are uniform and apply erga omnes, ${ }^{34}$ to ensure that one can objectively ascertain whether or not the terms, conditions, and procedure applicable to EU accessions have been complied with in any given case. ${ }^{35}$ In the case of the EU Treaties, the

\footnotetext{
34 This had been the case since the Treaty of Maastricht, which replaced the three different accession clauses in the founding Treaties with a single provision, Art. O TEU (now Art. 49 TEU). See also Case 93/78, Mattheus v Doego [1978] ECR 2203, where the ECJ interpreted former Art. 237 EEC (now Art. $271 \mathrm{TFEU}$ ) as establishing 'a precise procedure encompassed within well-defined limits for the admission of new Member States' (emphasis added), to be found not only in the enlargement procedure itself (including the Copenhagen criteria) but, arguably, also in the parts of the Treaties underlying the 'very foundations' of the EU, and including the general principles of Union law (see C Hillion, 'EU enlargement' in Craig and De Búrca (eds) Evolution of EU Law (OUP, Oxford 2011) 213). For a comprehensive and up-to-date legal appraisal of the general principles of EU law, see T Tridimas, The General Principles of the EU Law (2nd edn OUP 2009). For a legal analysis of former Art. 237 EEC, its evolution in the context of EU enlargement, and the delimitation of conditions of admission and pre-Treaty of Lisbon adjustments to the Treaties, see Laulhé Shaelou (n 13) 96-8.

35 The way in which the accession procedure is regulated in the TEU has been viewed, by some, as too modest, 'leaving the rest to customary rules and practice' (see Lazowski (n 2) fn 5; see also Tatham (n 2) 134). The political framework of EU enlargement created at the 1993 Copenhagen European Council may have initially belonged to the realm of intergovernmentalism but was then further elaborated on and 'systematized' in subsequent European Council meetings, and in Treaty revisions (starting with Amsterdam), including with reference to the basic accession conditions articulated in Copenhagen (see Hillion (n 34) 193-7). The Treaty of Lisbon has now advanced further this exercise of codification of past practices and routines with respect to the EU enlargement policy (including through an express reference in Art. 49 TEU to the 'conditions of eligibility agreed upon by the European Council' to be 'taken into account'), thereby bringing this policy clearly into the supranational realm of EU law despite arguably going beyond the perimeter of the EU acquis stricto sensu. As noted by a commentator, however, this codification process may still be incomplete: '[s] hort of a full codification of the post-Copenhagen substantive and procedural rules of enlargement
} 
terms and conditions in question are to be found in Article 49 TEU, to which the Treaty of Lisbon has inter alia added (by way of a supplementary precondition for EU accession) a reference to the Union's values, as per new Article 2 TEU. ${ }^{36}$ Besides, following the introduction by the Treaty of Lisbon of an exit clause, even a former Member State (ie one that has withdrawn) would need to comply with the procedure set out in Article 49 TEU if it wished to rejoin the EU. ${ }^{37}$ Despite the fact that, as argued earlier in this paper, Article 50 TEU is of no relevance to the secession scenario that is the focus of this paper, it seems difficult to argue that what applies to the whole should not apply to its parts: it is, in other words, difficult to argue that a former Member State should be treated less favourably than a newly created state entity resulting from secession that was never part of the European family as a sovereign state. Far from enjoying any right of automatic accession, the new state entity should therefore be expected to comply with the Treaties' enlargement conditionality policy as a condition precedent to its EU accession. ${ }^{38}$

Absent any dedicated primary law provision, and lacking any indication that, in a genuine secession scenario, EU law would, contrary to PIL, treat the seceding state entity as a successor state, ${ }^{39}$ newly created state entities wishing to join the ranks of the EU would need to forge their own relationship with the EU. Compliance with the Copenhagen criteria would be the foundation of that relationship. ${ }^{40}$ While a detailed examination of the Copenhagen criteria lies outside the scope of this paper, suffice it to note that, in order to join the $\mathrm{EU}$, applicant states need to demonstrate institutional stability, as a guarantee for democracy, respect for the rule of law and human rights and respect for (and protection of) minorities (the 'political criterion'). They also need to demonstrate the existence in their territory of a functioning market economy, their capacity to cope with competitive pressure and market forces within the EU,

[fn omitted], the Lisbon version of Art. 49 TEU ... goes a long way to consolidating past routines [fn omitted]' (see Hillion (n 34) 212).

${ }^{36}$ Eligibility is now subject to the values referred in Art. 2 TEU, which candidate countries must 'commit' to 'promote' (see Hillion (n 34) 211-12).

37 See Art. 50 (5) TEU.

${ }^{38}$ See for instance C Hillion, 'Enlargement of the EU: The Discrepancy between Accession Conditionality and Membership Obligations' (2004) 27 Fordham International Law Journal 715; M Cremona, 'Enlargement and External Policy' in M Cremona (ed.) The Enlargement of the EU (OUP, Oxford 2003); P-C Müller-Graff, 'Legal Framework for EU-CEEC Relations' in M Maresceau (ed.) Enlarging the EU (Longman, London 1997). The same views have been expressed by European Commission President Barroso in a letter to the Economic Affairs Select Committee of the House of Lords (see < http://www.publications.parliament.uk/pa/ld201213/ldselect/ldeconaf/ 152/15207.htm\#note133 >, last accessed on 6 January 2014) and, more recently, by European Council President Van Rompuy at a press conference with Prime Minister Rajoy in Madrid, on 12 December 2013 (see <http://www.consilium.europa.eu/uedocs/cms_data/docs/pressdata/en/ec/ 140072.pdf $>$ last accessed on 6 January 2014).

39 On the position under PIL, see the discussion under Section B of Part I.

40 These criteria were established by the Copenhagen European Council in 1993 and strengthened by the Madrid European Council in 1995 (see < http://ec.europa.eu/enlargement/policy/glossary/ terms/accession-criteria_en.htm., last accessed on 26 August 2013). 
and their ability to take on the EU's economic and monetary aims (the 'economic criterion'). Finally, applicant states would also need to accept and transpose the acquis. ${ }^{41}$ It is submitted that the very nature of the Copenhagen criteria militates against the existence of an automatic right of EU membership for newly created state entities: 'new-comers' would need to demonstrate, to the satisfaction of their prospective partners, that they fulfil the criteria in question, which do not, by their very nature, lend themselves to a mere presumption of compliance. In the case of newly created states, fulfilment of the Copenhagen criteria would appear all the more relevant than in the case of existing states, which will have already achieved membership of other international organizations, and obtained international recognition of their legal status.

In short, our conclusion is that newly created state entities would need to comply with the normal EU accession conditions and procedure before they can join the EU: they would, in other words, need to 'join the queue' of accession countries, ${ }^{42}$ provided they have been granted the status of a candidate country, ${ }^{43}$ and fulfil the admission criteria. The above conclusion is without prejudice to the factual possibility of a speedier accession in the case of a newly created state entity or, in extremis, of a 'simplified' accession procedure to reflect the fact that the newly created state entity is the product of separation from an existing Member State. These possibilities are examined in subsection (iii).

\section{(iii) A 'simplified' accession procedure?}

Once a candidate country has satisfied the admission criteria, it is for the European Council to decide on the opening of accession negotiations with it. The rationale of accession negotiations is to ensure the smooth integration in the EU of a prospective Member State, and to avert any negative socio-economic consequences of enlargement in both the new and the existing Member States ${ }^{44}$ The negotiation process is understood to play a central role in 'the Europeanisation of the national institutions and administrations of the acceding countries', and to form the 'final stage of a gradual process of preparing their public administrations to become full players in the multi-level system of EU

\footnotetext{
${ }^{41}$ Although not defined, as such, in the Treaties, the Union acquis has been described more precisely in the context of enlargement, in particular following the amendment of Art. 49 TEU by the Amsterdam Treaty (see, for instance, C Delcourt, 'The acquis communautaire: Has the Concept had its Day?' (2001) 38 Common Market Law Review 829, 831). The concept has been further detailed in explanatory texts relating to the enlargement process, including in the various Commission's Opinions on applications for accession to the EU (see, for instance, L Maurer, 'Negotiations in progress' in A Ott and K Inglis (eds), Handbook on European Enlargement (TMC Asser Press, The Hague 2002) 116. For a comprehensive analysis of the Union acquis in the context of enlargement and EU integration, see Laulhé Shaelou (n 13) 20-4; and Tatham (n 2) 131-5.

42 See Weller (n 12) 1.

43 On the determination and application of the political criteria of enlargement, conditionality, and the procedure for membership see, for instance, Tatham (n 2) 131-4.

${ }_{44}$ See P Van Elsuwege, From Soviet Republics to EU Member States (Brill/Martinus Nijhoff Publishers, Leiden 2008) 309-10.
} 
policy and decision-making. ${ }^{45}$ Would the conventional rationale of accession negotiations also apply to a seceding state entity?

It should first of all be noted that there are a number of issues that seem unlikely to be settled without prior accession negotiations (for instance, the votes in the Council that the new member would have, or the number of seats it would have in the European Parliament). On the other hand, it could be argued that, having formerly been part of an existing Member State, and having, as a result, enjoyed the benefits and carried (some of) the weight of EU membership, there would be relatively little that a seceding state entity could hope to learn from a 'fresh' EU accession negotiation process. Indeed, in some instances, the seceding state entity may already have been in the position of a 'full player... in the multi-level system of EU policy- and decision-making' through sub-national representation and governance. ${ }^{46,47}$ The national learning process could therefore be limited when it comes to the 35 negotiation Chapters of the acquis of common standards of law, institutions, and practice within the $\mathrm{EU}$, and the same may turn out to be true of the actual duration of the accession negotiations. It would indeed seem plausible that, compared to the accession process for other candidate countries, the accession process for a seceding state entity would prove to be 'faster and easier', given the latter's familiarity with EU policies, rules, and laws (although much would also depend on the capacity and efficiency of the newly created state entity's administration to deal with the large body of EU acquis). Moreover, presumably for the same reasons, it might be argued that, albeit mandatory in nature, the accession process for a newly created state entity could be 'simplified', and that 'special arrangements' with it might be possible, with the unanimous support of all other Member States (including the rump Member State). ${ }^{48}$ What would 'simplified' mean in this particular context?

\footnotetext{
45 Ibid 310.

46 The importance of regional and local self-government is acknowledged in Art. 4(2) TEU, which is to be read in conjunction with the principle of non-involvement of the EU in the internal affairs of the Member States, also enshrined in the same Treaty provision (see Matas et al (n 33), 48).

47 The 'new dynamics' in Member States' governance illustrated by regions and local selfgovernments is also reflected in other provisions of the EU Treaties, including at the institutional level. For Spain's representation at the European Parliament see <http://www.europarl.europa. $\mathrm{eu} / \mathrm{meps} / \mathrm{en} / \mathrm{search} . \mathrm{html}$ ?country=ES $>$ where members of the various Catalan political parties sit as MEPs; for Scotland's representation at the European Parliament see $<$ http://www.europarl. europa.eu/meps/en/search.html?country=GB $>$; see also the Committee of the Regions, where Catalonia is represented by its President and Scotland by members of its parliament as well as by one member of the Scottish Borders Council <http://memberspage.cor.europa.eu/ SearchByCountry.aspx $>$, all last accessed on 26 August 2013).

48 The rump Member State would obviously have the option to veto the EU accession of the seceding state entity (see Happold (n 5), 33-4). A consensus between the rump Member State and the new State entity would need to be found in order for the accession process to proceed. It is telling that, referring to Scotland, Crawford and Boyle have argued that its position within the EU 'is likely to be shaped more by any agreements between the parties than by pre-existing principles of EU law' (see Crawford and Boyle (n 15) 68). In this regard, also see the Agreement between the UK government and the Scottish government on a referendum on independence for Scotland, 15 October
} 
Post-Treaty of Lisbon, it might be argued that the accession procedure could be adjusted within the fabric of Article 49 TEU. ${ }^{49}$ In particular, revised Article 49 TEU provides that, '[ $t$ ] he conditions of eligibility agreed upon by the European Council shall be taken into account' (emphasis added). Inherent in the above formulation is the power of the European Council to adjust the enlargement procedure, beyond the boundaries of Article 48 TEU. ${ }^{50}$ So far it has been possible to proceed with adjustments with regard to EU membership both ex ante (during the pre-accession strategy in particular) and ex post, ${ }^{51}$ in continuation of the post-accession conditionality policy, as illustrated in the case of the 2004 enlargement. ${ }^{52}$ The latter type of adaptations to the Treaties have been said to provide a degree of flexibility within the EU legal order, despite the fact that the basic constitutional framework of European integration must, in principle, be accepted and implemented by all prospective members in the same way. ${ }^{53}$ Post-Treaty of Lisbon, and given the powers seemingly granted to the European Council under Article $49 \mathrm{TEU}$, the question arises what type of adjustments to the Treaties would be covered, ${ }^{54}$ and whether a 'simplified' accession process would represent a permissible adjustment, within the meaning of Article 49 TEU.

In the authors' opinion, the term 'simplified' should in this particular context be understood to mean a 'bilaterally negotiated process leading to accession', with the term 'accession' standing for full EU membership, rather than for any another type of special relationship as an alternative to EU membership. ${ }^{55}$ Moreover, any 'simplified' accession process, whatever its form and details,

2012, <http://www.scotland.gov.uk/About/Government/concordats/Referendum-on-independ ence> last accessed on 26 August 2013.

49 According to a commentator, the Treaty of Lisbon 'codifies the European Council's ability to adjust the enlargement procedure' (Hillion (n 34) 212). The exercise of this power would inevitably raise proportionality issues (see Tridimas (n 34) 193).

${ }^{50}$ Hillion (n 34) 212. For an illustration of this power before its formalization by the Treaty of Lisbon, see Laulhé Shaelou (n 13) 45-51 and 180, with respect to the 2002 Copenhagen summit and the 2004 enlargement process.

${ }^{51}$ Müller-Graff (n 38) 39.

52 See, for instance, K Inglis, 'The Pre-accession Strategy and the Accession Partnerships' in Ott and Inglis (n 41); M Cremona (ed.) The Enlargement of the EU(OUP, Oxford 2003); C Hillion, 'The EU is Dead. Long Live the EU ... A Commentary on the Treaty of Accession 2003' (2004) 29(5) EL Rev 588; and C Hillion (ed.), EU Enlargement, a Legal Approach (Hart, Oxford 2004).

53 Müller-Graff (n 38) 36.

${ }^{54}$ It is reasonable to assume that the 'hard core' of EU law (touching upon the fundamental principles and constitutional foundations of the EU), would not fall under the European Council's competence formalized in Art. 49 TEU.

55 With reference to the different 'modes of adjustment' of a candidate state 'to the status and the dynamics of integration', as identified by Müller-Graff, there are three main modes, the strongest one being full membership, the second being 'the association of non-member states within a member-like relations, and the third being various sorts of partial integration' (Müller-Graff (ed.), East Central Europe and the EU: from Europe Agreements to a Member Status (Nomos, Baden-Baden 1997), 39. Also see A Lazowski, 'Enhanced Multilateralism and Enhanced Bilateralism: Integration without Membership in the EU' (2008) 45 Common Market Law Review 1433; and A Evans, The Integration of the EC and Third States in Europe (Clarendon Press, Oxford 1996). 
would (a) require the unanimous consent of all Member States, in accordance with Art. 49 TEU, and (b) derive from the accession process itself rather than being a pre-condition for the opening of such a process. This last argument, it is submitted, takes the analysis further away from other potential sources of comparison such as Germany's situation upon reunification, where the absorption of former East Germany by the Federal Republic of Germany occurred without any need for accession negotiations. ${ }^{56}$ It could be argued that the German case was the result of a conditional process aiming at the reunification of the country, distinct from an enlargement process. ${ }^{57}$ The German example is therefore to be distinguished from the situation under consideration in this paper, which involves a state entity created through its separation from one of the existing Member States but willing to be part of the EU. Such a newly created state entity would need to undergo an accession process proper as opposed to merely requiring Treaty adjustments to facilitate its accession ${ }^{58}$. Finally, in the opinion of the authors, no 'simplified' accession process could ever result from the triggering of a 'passerelle clause', whereby simplified rules would apply, as distinct from the ordinary (general) rules. ${ }^{59}$

\footnotetext{
56 See, for instance, F Scharpf, 'The joint-decision trap: lessons from German Federalism and European integration' (1988) 66 Public Administration 239; see also AS Krossa, 'Integration of Unequal Units: Comparing the German and the European Unification Process' (2007) 3(1) Journal of Contemporary European Research 1; and M Gruel-Dieudé, Chypre et l'UE: mutations diplomatiques et politiques (L'Harmattan, Paris 2007), 136-47.

57 In an application of the presumption of state continuity, the Länder of the former German Democratic Republic acceded to the Federal Republic of Germany on 3 October 1990, by virtue of Art. 23 of the Basic Law of the FRG. As a result, EU law became applicable in the former GDR and the Council merely adopted a package of adjusting and transitional measures to deal with the impact of the German reunification (see 'Package of measures proposed by the Commission for the German reunification' $\operatorname{COM}(90) 400$ final (1990) 4 EC, adopted by the Council [1990] OJ L 353/1, 17 December 1990; see also D Spence, 'Enlargement without Accession: the EC's Response to German Unification', Discussion Paper 36, The Royal Institute of International Affairs, London, 1991, 17; and Laulhé Shaelou (n 13) 176 and 242). No Treaty revision was therefore necessary in the German case.

58 Originally, Treaty adjustments were meant to address changes 'closely connected to an individual State': institutional changes, official language, territorial scope of the Treaties. The definition of the term 'adjustments' has arguably become broader over time, to encompass changes not 'intrinsically' connected to enlargement but 'politically convenient', hence the need to address these in an enlargement process, for fear of 'smuggling in' Treaty amendments on the occasion of a forthcoming
} enlargement (see B De Witte, 'Treaty Revision Procedures after Lisbon' in A Biondi et al (eds), EU Law after Lisbon (OUP, Oxford 2012) 125). De Witte refers to the European Council's decision taken on 18-9 June 2009 (Presidency Conclusions, para. 5(iv), available at $<$ http://www.consilium. europa.eu/uedocs/cms_data/docs/pressdata/en/ec/108622.pdf > , last accessed on 26 August 2013), which arguably 'endorsed' this wider reading of the term 'adjustments' by agreeing that the Decision on Ireland 'would be elevated to the status of Treaty Protocol on the occasion of the first accession of a new Member State' (ibid 116 and 125). See also Peers (n 11) 17 and fn 5, 28.

59 With respect to overseas and other semi-autonomous territories of Member States, ordinary Treaty amendment procedures contained in Art. 48(2)-(5) TEU or the simplified procedures outlined in Art. 48(6)-(7) TEU would not apply to amending the status of the Danish, French, and Netherlands territories (OCTs and ORs) but Art. 355(6) TFEU would. This provision sets out the possibility for a simplified status change ('passerelle clause') and, as such, constitutes a derogation from the general rules on Treaty revision (see Kochenov (n 27) 61). For a detailed legal analysis of 
One of the key aspects of a 'simplified' accession process would be the aspect of timing. It is clear that there can be no pre-determined timeframe in an accession process, which can go on for as long as necessary to achieve results, ${ }^{60}$ and may even extend beyond a new Member State's actual accession (for instance, where long transitional periods or safeguard clauses are at play). ${ }^{61}$ Having said that, applying by analogy the spirit of Article 50 TEU, ${ }^{62}$ it could be argued that the period of time ${ }^{63}$ indicated in that provision for the negotiation of a Member State's withdrawal from the EU ${ }^{64}$ could also apply to the accession process of a newly created state entity, within the meaning of this paper, in order to compensate for the potentially little 'added-value' of its accession process. ${ }^{65}$ From the timing point of view, 'simplified' would mean accelerated or expedited, but without touching upon the substance of the accession process, which would remain intact and whose outcome would still have to be the product of negotiations, including over non-legal issues. ${ }^{66}$

passerelle clauses in the Treaties, including the 'general passerelle' under Art. 48(7) TEU and 'passerelles spéciales' see De Witte (n 58) 123. For a critical analysis of Art. 48(6) TEU, see De Witte (n 58) 124-5; and, more generally, Peers (n 11) 32-42.

60 The obvious example would be Turkey's accession process, which is the longest, so far, of all accession processes, and which remains suspended and incomplete to date (see Laulhé Shaelou (n 13) 44-5; and Tatham (n 2) 133 and 137). There can also be procedural and substantive barriers hampering good and prompt progress towards accession, inherent in Art. 49 TEU itself, especially post-Lisbon (eg the reference in it to Art. 2 TEU and to the promotion of the Union's values, parliamentary participation through their 'notification' of an application for membership) — see Tatham (n 2) 135-6).

61 See Tatham (n 2) 137 and fn 57 with respect to the 2003 and 2005 Acts of Accession.

62 Despite their different scope, which means that Articles 49 and 50 TEU cannot be regarded simply as the obverse and reverse of the same coin' (Tatham (n 2) 128), these two provisions are linked to one other (it is no coincidence that these two provisions follow one another in the final provisions of the TEU).

63 It should be noted that the same two-year period also appears in Art. 48(5) TEU with respect to the ordinary revision procedure, in the event that the ratification process runs into difficulties in one or more Member States.

${ }^{64}$ Art. 50(3) TEU. Unlike in the case of the activation of the exit clause, the EU accession of a newly created state entity could not be deemed to have occurred upon the expiry of a specific period of time (hence the absence of any express reference to a timeframe in Art. 49 TEU, unlike in the case of Arts 48 and 50 TEU).

65 This may not be true of a new state entity having gained independence from a Member State benefiting from specific opt-outs in key EU policy areas, as in the case of the UK (which has negotiated opt-outs from the single currency as well as from cooperation in justice and home affairs).

${ }^{66}$ It is beyond the scope of this paper to explore such considerations, the costs of which may be a determining factor, as they are likely to be high. In the case of Scotland see G Avery, 'The Foreign Policy Implications of and for a Separate Scotland', available at <http://www.publications.parlia ment.uk/pa/cm201213/cmselect/cmfaff/writev/643/m05.htm>; 'Scottish Independence and the EU-a Poor Fit', available at <http://www.publicserviceeurope.com/print-article.asp? id=2387>; D Furby, 'Scottish Independence and EU Accession' (Business for New Europe, 2012) <http:// www.bnegroup.org/images/uploads/publications/files/In_Depth_Scottish_Independence_and_ EU_Accession_-_BNE_March_2012_1.pdf $>$; and A Thorp and G Thomson, 'Scotland, Independence and the EU' (Commons Library Standard Note SN/IA/6110, 2011) <http://www. parliament.uk/briefing-papers/SN06110>, all last accessed on 26 August 2013). 
Thus, it would appear that, (a) for the reasons set out in subsection (ii), a newly created state entity, recognized under PIL, ${ }^{67}$ would need to be the subject of an accession process in accordance with Article 49 TEU (provided its accession efforts are not hampered by an existing EU Member State, including through use of the 'double' veto option deriving from Article $49 \mathrm{TEU}^{68}$ ), (b) the accession process for a seceding state entity could nevertheless turn out to be 'faster and easier' than the process for other candidates, and (c) the accession process could be further accelerated through the negotiation of adjustments to the EU Treaties, to be addressed within the fabric of Article 49 TEU. ${ }^{69,70}$

In light of the above, the only outstanding question would appear to relate to the acquired rights of the rump Member State (and its (ex) nationals), and their impact on the debate surrounding the newly created state entity's rights of accession to the EU. The issue of acquired rights is examined in the following subsection.

\section{(iv) The relevance to the debate of acquired rights}

Absent an automatic right of accession to the EU enjoyed by a newly created state entity, and given the presumption of continuity for the (rump) Member State under PIL, ${ }^{71}$ the issue of the allocation of acquired rights between the rump Member State and the newly created state entity would appear straightforward: such rights would continue being exercised by the rump Member State in its new form (even if subject to certain adjustments to reflect the reduction in its territory and population); ${ }^{72}$ at the same time, there should, a priori, be no room for the acquisition or shared enjoyment of such rights by the seceding state entity, ${ }^{73}$ which would have to start a fresh process of accession, and negotiate its

\footnotetext{
67 This aspect would need to be addressed first, as the creation and the existence of a new State would be a pre-condition for EU accession talks to take place. Contra Matas et al who argue that the main objective of the exercise would be 'the modification of the provisions of the Treaties of constitution to adapt to the new situation derived from state succession in case of secession or dissolution of a member state' (see Matas et al (n 33) 71-2).

68 At the Council level and subsequently during the process of national ratification-this point is especially crucial for Member States having their own secessionist movements.

69 For the purposes of this paper, a cursory comparison between the Negotiating Frameworks for Iceland and Turkey suffices to illustrate the existence of elements of differentiation in EU enlargement within the scope of Art. 49 TEU, whereby both the EU and Member States need to 'strike a balance' between 'common core' and individual criteria for a given applicant country (see Tatham (n 2) 135). For a socio-legal analysis of the theoretical framework of differentiation with respect to the 2004 enlargement, see Laulhé Shaelou (n 13).

70 The willingness to proceed with such adjustments may, of course, be hampered by the EU's disinclination to accelerate the accession process so as to avoid setting a precedent that others may wish to benefit from (see Furby (n 66) 1).

71 On the position under PIL, see the discussion under Section B of Part I.

72 The reader is referred to the discussion under subsection (i) of Section A of Part I.

73 Contra Avery (n 66) points 14-5.
} 
own accession terms and conditions. ${ }^{74}$ This would, in practical terms, entail a large time gap between the moment when the seceding entity becomes an independent state under PIL and the moment when the process of its EU accession is eventually completed. During this period (the length of which cannot be pre-determined), all of the rights previously enjoyed by the entity (and its people) at the time that it was still part of a Member State would normally cease to apply, with no new rights replacing them until the seceding state entity has joined the EU. As a result, there would inevitably be a vacuum in the enjoyment by the entity and its people of rights flowing from their former participation in and membership of the EU. ${ }^{75}$

Although there could be some room, at least in theory, to support the continuing application of EU law in the seceding state entity for the interim period between independence and EU accession, ${ }^{76}$ it is submitted that nothing short of negotiations would suffice to determine the extent and terms of the application of EU law in a newly created state entity during the interim period. The example of Algeria, when it gained its independence from France in 1962, could be of some relevance here, ${ }^{77}$ to the extent that Algeria's secession from France was accompanied by its withdrawal from the European Communities (EC) but, also, resulted in the continued-albeit limited-application of EC law in Algerian territory. ${ }^{78}$ Algeria's withdrawal from the EC was not addressed expressly during the bilateral negotiations that led to Algerian independence. However, following Algerian independence, the Algerian President requested from the Council the 'maintenance' (or retention) of the application of certain Treaty provisions, 'pending future definition of EC-Algeria relations'. ${ }^{79}$ This appears to imply that during the period between Algeria's declaration of independence (on 1 July 1962) and its request for the continuing application to it of certain Treaty provisions (on 24 December 1962) —and arguably even beyond, at least until consideration of the request by the Community institutions-such provisions of EU law as may have continued to apply to Algeria only did so 'tacitly' and 'by implication', and 'without any official overtures either from that

${ }^{74}$ In particular, it is clear that any 'opt-outs' available to the rump Member State would not apply mutatis mutandis to the seceding State entity, which would need to negotiate transitional measures, safeguard clauses or other types of measures, prima facie temporary in nature, both with the EU and with other Member States (see Laulhé-Shaelou (n 13), 98-9).

75 This is also true of Member States' obligations deriving from the EU Treaties, as there will be at first no state entity in international law and, subsequently, no obligations under EU law on the newly created state entity as a 'third country'.

${ }^{76}$ Arguments in favour of the continuing application of EU law in the seceding state entity for the interim period could in particular be derived from considerations of legal certainty, legitimate expectations and, possibly, equal treatment as per Art. 4(2) TEU (see Peers (n 11), 60 and fn 251).

77 See Crawford and Boyle (n 15) 99.

78 Algeria was subject to the Treaty provisions under Art. 227(2) EEC (inter alia on free movement of goods, agriculture, liberalization of services, competition, and institutions—see Tatham (n 2) 144 and fns 103 and 104).

79 Ibid 144; also see P Tavernier, 'Aspects juridiques des relations économiques entre la CEE et l'Algérie' (1972) 8 Revue trimestrielle de droit européen 1, 9-10. 
state or the Community'. ${ }^{80}$ While receipt of the request was acknowledged by the Council in January 1963, and was assessed positively by the Commission, ${ }^{81}$ it is unclear whether the relevant Treaty provisions continued to apply until the conclusion of the first EC-Algeria bilateral agreement in 1976. ${ }^{82}$ Algeria not being a European state, and having initially been subject to a special regime, it was obvious that, in the absence of a framework for the 'soft' application to it of the relevant EC rules, all benefits derived from its former EC membership would have been lost, at least until a bilateral agreement on the relations between the EC and Algeria had been reached. ${ }^{83}$ Drawing on the example of Algeria, we conclude that the continuing application of EU law in a newly created state entity would need to be expressly addressed in the course of bilateral negotiations taking place during the interim period. ${ }^{84}$ While the desire to bridge the gap during the interim period may be understandable, achieving that in practice appears difficult, ${ }^{85}$ even through an association agreement characterized by an 'intense degree of integration' and, potentially, including some elements of continuing application of EU law. ${ }^{86}$ The newly created state entity could, of course, decide to maintain, on a voluntary and unilateral basis, the application of certain EU law provisions: this, however, would not cause the new state entity or its people to retain any rights or obligations under the Treaties, which would be dependent upon full membership. ${ }^{87}$

The vacuum created during the interim period in the enjoyment of the rights deriving from EU membership would have implications not only for the newly created state entity but, also, for its subjects. ${ }^{88}$ Secession arguably leads to a fundamental change in the collective status of the nationals of a newly created

\footnotetext{
80 See Tatham (n 2) 150.

81 'Assuring the Community's respect for former responsibilities, especially in financial matters', see Tatham (n 2) 144 and fnn 110 and 111.

82 As a commentator has aptly argued, there were signs in the relationship between Algeria and the EU that 'neither side wished to see a sudden and complete rupture between them, and they thus allowed an intermediate legal situation to continue due to important political and economic considerations, especially in relation to France' (see Tatham (n 2) 145).

83 EEC-Algeria Cooperation Agreement, 26 April 1976 [1978] OJ L 263/2. The reference to Algeria in the Treaties was subsequently deleted by the Maastricht Treaty; see Peers (n 11), 58.

${ }^{84}$ For the possibility of negotiations 'by analogy with the position of withdrawing Member States' in the period between the recognition of the secession of the entity concerned and the official date of such secession, see Peers (n 11), 60. Such negotiations would, however, need to remain informal, as the EU can only negotiate with a state recognized as such under PIL. As previously indicated it is logical that, for practical reasons, Member States may prefer to negotiate and adopt one set of measures combining various forms of Treaty amendment, if needed, rather than be involved in distinct negotiation processes to address the situation of the seceding State entity and/or of the rump Member State.

85 See Crawford and Boyle (n 15) 103.

86 See Peers (n 11) 62.

87 See Crawford and Boyle (n 15) 103.

88 See in this respect a parliamentary question to the Commission by Mara Bizzotto about the possibility of secession in a Member State and the impact on citizens, 25 July 2012, available at $<$ http://www.europarl.europa.eu/sides/getDoc.do?type=WQ\&reference=E-2012-007453\&lan guage $=\mathrm{EN}>$, as well as the answer from the Commission given by European Commission President
} 
state entity, who would normally (even if not necessarily) lose the nationality of the predecessor Member State and, by implication, also the right to enjoy the benefits of EU Citizenship. ${ }^{89}$ Since EU citizenship is 'contingent' upon its beneficiary's possession of the nationality of one, at least, of the Member States,${ }^{90}$ the citizens of a newly created state entity would not fall within the scope of the Treaties pending EU accession, leading to their material incapacity to enjoy, during the interim period, the individual rights and benefits deriving from EU Citizenship. ${ }^{91}$ In any given legal order, the exercise of acquired rights accruing to individuals normally depends upon national-level decisions, confirming the link between individual rights (including rights of citizenship) and the state. Specifically in the case of the EU legal order, the above statement may call for some qualification to the extent that an additional layer of rights and entitlements exists, granted to individuals at the supranational level and deriving from EU law. ${ }^{92}$ Thus, where state decisions have a direct, negative impact on the enjoyment of those very individual rights derived from $\mathrm{EU} \mathrm{law}^{93}$ - as in the scenario that is the focus of this paper, where EU law-derived legal rights would

Barroso, 28 August 2012, available at <http://www.europarl.europa.eu/sides/getAllAnswers. do? reference $=$ E-2012-007453\&language $=E N>$, both last accessed on 29 August 2013.

${ }^{89}$ Art. 20(1) TFEU clearly provides that EU citizenship is 'additional' to national citizenship (see P Craig and G De Búrca, EU Law (5th edn OUP, Oxford 2011) 821. Before the term 'additional' was inserted into the TEU by the Treaty of Lisbon, the nature of the relationship between national and EU Citizenship had already evolved through the case law of the Court of Justice of the European Union (CJEU), leading, according to a commentator, to the gradual — but still relative and limited absorption of national citizenship within Union citizenship (G Davies, 'The Entirely Conventional Supremacy of Union Citizenship and Rights' in J Shaw (ed.) 'Has the ECJ Challenged Member State Sovereignty in Nationality Law?' EUI Working Papers, RSCAS 2011/62, 5 available at <http:// eudo-citizenship.eu/docs/RSCAS_2011_62.pdf > last accessed 26.08.2013. Davies talks about 'citizenship pluralism' in order to describe the relationship between the national and the EU level of citizenship, both levels being 'intertwined in a mutually dependent way, neither able to develop without taking account of the other' (ibid 9). Kostakopoulou points to their interaction, 'without affirming an explicit or implicit hierarchy of statuses' (D Kostakopoulou, 'EU Citizenship and Member State Nationality: Updating or Upgrading the Link' in the same volume, 21).

90 See Craig and De Búrca (n 89) 821. This is so despite efforts during the Convention on the Future of Europe to 'de-link' EU citizenship from the nationality of Member States, linking it, rather, to stable residence in the EU. For more details see <http://european-convention.eu.int/ $>$, last accessed on 29 August 2013. With respect to this debate in the context of the Treaty of Lisbon, see N Reich, 'The Constitutional Relevance of Citizenship and Free Movement in an enlarged Union' (2005) European Law Journal 11; and Van Elsuwege (n 44) 448-9. Kochenov describes the relationship between the two legal statuses as being 'connected through acquisition: enjoying one is a precondition to possessing another' (Kochenov, 'Two Sovereign States vs. a Human Being: CJEU as a Guardian of Arbitrariness In Citizenship Matters' in J Shaw J (ed.) 'Has the ECJ Challenged Member State Sovereignty in Nationality Law?' EUI Working Papers, RSCAS 2011/62, 11-5, 12. The recently announced plans of the Maltese authorities to sell Maltese passports to wealthy non-EU nationals, allowing them to become established across the EU, is telling of the lingering perception of nationality law as an issue of domestic interest, despite its immediate link to EU citizenship.

${ }^{91}$ As set out in Art. 21(2) TFEU and interpreted by the CJEU in its case law; see eg Craig and De Búrca (n 89) 820-53.

92 Through the status of EU Citizenship in particular, as recognized by the CJEU in its case law. 93 See Davies (n 89) 6. 
automatically cease to apply in the seceding state entity's territory following a change of sovereignty ${ }^{94,95}$ - one may want to query whether it might be possible to differentiate between the territorial scope of application of EU law deriving from EU membership (which will have been lost automatically upon secession) and its personal scope of application to individuals settled within the seceding territory (which may need to 'survive' secession in some respects, if individual rights are to be protected). It would, after all, only be reasonable to expect the fact that certain individuals were formerly EU citizens to be something that cannot be ignored, if those individuals are not to be deprived, through the (unilateral) act of secession, of rights that accrued to them personally under the status quo ante. ${ }^{96}$

In the light of the above, the question arises what the nature and scope of the proposed continuing application ratione personae of EU law may be in the scenario that is the focus of this paper. ${ }^{97}$ This question is addressed in subsection (v), with an emphasis on the right of EU Citizenship.

\footnotetext{
94 See Matas et al (n 33) 41 and 47.

95 It is argued that this would not amount to a 'wholly internal situation' escaping the reach of EU law, in line with the Court's case law on 'sub-State' entities such as autonomous regions or territories of Member States. For an example, see Case C-212/06, Government of the French Community and Walloon Government v Flemish Government [2008] ECR I-1683, paras 38-40. For other cases of relevance to 'sub-State' entities, see Case C-428/07, The Queen, on the application of Mark Horvath $v$ Secretary of State for Environment, Food and Rural Affairs [2009] ECR I-6355 as well as the Azores and Basque Country tax cases between 2006 and 2008. Also see D Edward and J Bengoetxea, 'The Status and Rights of Sub-state Entities in the Constitutional Order of the EU' in Arnull et al, $A$ Constitutional Order of States? Essays in EU Law in Honour of Alan Dashwood (Hart, Oxford 2011) 35-7.

96 The implications of the collective withdrawal of the substance of EU citizenship rights from (former) nationals of a Member State come to light in particular in the context of overseas territories if one considers that the EU Treaties do not make any connection between the acquisition or the loss of the status of EU citizenship and the place of residence (see Case C-300/04, Eman and Sevinger [2006] ECR I-8055, paras 29-31). The Court clarified in this case that the internal movement between the territories of a Member State lying 'within and outwith' the territorial scope of EU law does not result in the loss of EU citizenship (paras 29-31; see Kochenov (n 27) 205). Such a move could, however, affect the legal status of the Union citizen as far as the enjoyment of rights is concerned. After this case and as argued by Kochenov, 'it is abundantly clear that the ability of the Member States to deprive their nationals of EU citizenship through legal constructions built around the concept of residence is very limited indeed', even if it remains a possibility (Kochenov (n 27)205). It is only natural after all that the limited scope of EU law, in space in particular, carries with it some adverse implications, including on the extent of EU citizenship rights (free movement provisions, political rights but also the principle of non-discrimination) and their exercise (see Kochenov (n 27) in and/or out of the EU territory, 215-19), as appears to be the case in the scenario under study in this paper.

$97 \mathrm{On}$ the different scope ratione loci, ratione materiae, and ratione personae of EU law and the Member States' room for manoeuvre to decide who is an EU citizen and what the ius tractum nature of EU citizenship is, see Kochenov (n 27); also see D Kochenov, 'Ius Tractum of Many Faces: European Citizenship and a Difficult Relationship between Status and Rights' (2009) 15(2) Columbia Journal of European Law 169.
} 


\section{(v) EU Citizenship, fundamental rights, and state secession}

Although EU law does not regulate the conditions for the conferral, by the Member States, of nationality (on which EU Citizenship is conditional), ${ }^{98}$ it follows from the case law of the European Court of Justice (ECJ) that national citizenship law is not entirely independent of EU law, and should respect its principles to the extent that it can have an impact on the enjoyment by individuals of their EU law-derived rights. ${ }^{99}$

With its rulings in Micheletti, ${ }^{100}$ Garcia Avello, ${ }^{101}$ and, more recently, Rottmann, ${ }^{102}$ the Court of Justice of the European Union (CJEU) has established a link between national citizenship and EU law. In particular, the CJEU has ruled that, "EU citizenship is destined to be the fundamental status of Member State nationals, enabling those who find themselves in the same situation to enjoy within the scope of the Treaty the same treatment in law irrespective of their nationality...' 103 In its rulings, the CJEU has also provided guidance on which aspects of national citizenship law may fall under its jurisdiction. While it has been suggested that all aspects of citizenship law should, eventually, fall within the scope of EU law, to the extent that they impact upon the ability of individuals to enjoy their EU Citizenship rights, ${ }^{104}$ this remains, for the time being, no more than an aspiration as the CJEU's ruling in Rottmann demonstrates. ${ }^{105}$

Rottmann offers interesting insights into the world of deprivation of rights deriving from EU Citizenship as a result of the stripping of nationality. The Court considered the notion of statelessness in the EU legal order with reference to international law, ${ }^{106}$ confirming that the proviso initially formulated in paragraph 10 of Micheletti that 'due regard' must be paid by Member States to EU

\footnotetext{
${ }^{98}$ Declaration No 2 on Nationality of a Member State appended to the Maastricht Treaty clearly states that the question of nationality is determined by reference to national law.

${ }^{99}$ A detailed account of the Court's case law on EU citizenship lies outside the scope of this paper. For an account of the relevant case law see, generally, J Shaw (ed), 'Has the ECJ Challenged Member State Sovereignty in Nationality Law', EUI Working Papers, RSCAS 2011/62; Craig and De Burca (n 89) 820-53; and Davies (n 89).

100 Case C-369/90 Micheletti v Delegación del Gobierno en Cantabria [1992] ECR I-4239.

101 Case C-148/02 Garcia Avello [2003] ECR I-1163.

102 Case C-135/08 Rottmann v Freistadt Bayern [2010] ECR I-1449.

103 Case C-184/99 Grzelczyk [2001] ECR I-6193, para 31.

104 See Davies (n 89), 8.

105 See O Golynker, 'The correlation between the status of Union citizenship, the rights attached to it and nationality in Rottmann' in J Shaw (ed), 'Has the ECJ Challenged Member State Sovereignty in Nationality Law?,'EUI Working Papers, RSCAS 2011/62, 19.

106 The reference is to the Convention on the Reduction of Statelessness, the European Convention on Nationality, and the Universal Declaration on Human Rights (see Rottmann (n 102) paras 52-3). On the attribution of nationality of the successor state in accordance with the International Law Commission's Articles on the Nationality of Natural Persons in Relation to the Succession of States, see Crawford and Boyle (n 15) 104-5. Also see A Abat, 'Catalan Internal Enlargement', NEEWS (New Emerging European Western States) available at $<$ http://www.international-view.cat/PDF/ civ\%207/CIV\%207\%20Antoni\%20Abat.pdf> last accessed on 29 August 2013.
} 
law when exercising their powers in the sphere of nationality is without prejudice to the firmly established principle of international law that Member States have the power to lay down rules governing the acquisition and loss of nationality. ${ }^{107}$ The Court has since been criticized for not going far enough to ensure the autonomy of EU law vis-à-vis international law in this respect, and for failing to introduce a sufficient degree of predictability in the interaction between national and EU law on the issue of nationality. ${ }^{108}$ However, following the Court's ruling in Rottmann, it has at least become clear that the revocation and/or withdrawal of EU Citizenship (as opposed to its initial granting) ${ }^{109}$ are matters of interest to EU law, to the extent that the act of taking away an individual's nationality deprives that individual of the status of an EU citizen and of the benefits attaching thereto (inter alia the rights to free movement, establishment, and equal treatment). ${ }^{110}$ Rottmann has also been criticized for leaving the application of the principle of proportionality (a necessary safeguard to ensure that national authorities pay 'due regard' to EU law and to the consequences of their actions for the person concerned under EU law when exercising their powers in the sphere of nationality) to the discretion of the national courts, ${ }^{111}$ despite regarding the deprivation of rights deriving from the EU Citizenship as matters of supranational interest. ${ }^{112}$ Perhaps more crucially for the purposes of this paper, Rottmann suggests that, de lege lata, EU Citizenship is not (yet) an autonomous fundamental right, and that it may be some time

\section{Rottmann (n 102) paras 39, 45, and 48.}

108 The CJEU's approach in Rottmann diverged from the approach taken in Micheletti, where the Court dismissed a 'potentially harmful' rule of international law in favour of a solution better adapted to the specificities of the EU legal order (see Kochenov (n 90) 12-14. Rottmann also sits uncomfortably with the Court's ruling in Kadi where the Court showed its willingness to provide clear and legitimate fundamental rights safeguards through a full and rigorous judicial review of the lawfulness of all EU acts, including those designed to implement UN Security Council resolutions: adopting a 'constitutionalist' approach to the protection of fundamental rights, the Court showed that it would only consider compliance with international obligations if they were 'harmonious' with the general principles of 'fundamental rights norms' as developed in its case law (Joined Cases C-402/ 05P and C-415/05P, Yassin Abdullah Kadi and Al Barakaat International Foundation v Council of the European Union and Commission of the European Communities [2008] ECR I-6351, para. 326). The CJEU appears to have just confirmed and reinforced its constitutionalist approach in Kadi II (see Joined Cases C-584/10 P, C-593/10 P, and C-595/10 P, Commission, Council, UKv Yassin Abdullah Kadi, 18 July 2013, not yet reported).

109 In Rottmann, the Court distinguished the situation of the applicant to that of the applicant in Kaur (Case C-192/99, The Queen v Secretary of State for the Home Department, ex parte Manjit Kaur, intervener: Justice [2001] ECR I-1237), where a third country national did not meet the definition of a national of a given Member State and could not therefore as such be deprived of the rights deriving from the status of Union citizen, which he had never enjoyed in the first place (Rottmann (n 102) para. 49).

${ }^{110}$ A commentator has drawn attention to an apparent separation between the rules of acquisition of citizenship, which remain at the national level, and those on its loss, which have partly moved to the supranational level following Rottmann, an 'untenable half-way solution' where the EU and national statuses 'are separated in terms of rights, but their acquisition and loss are not' (Kochenov (n 90) 12-13).

111 See Rottmann (n 102) para. 55.

112 See Kochenov (n 90) 12 and 14. 
before it attains this status. ${ }^{113}$ However, it has been suggested that, following Rottmann, the loss of the nationality of a Member State would not, for all intents and purposes, place an individual 'outside the scope of EU law': loss of nationality is, instead, 'a restriction on the rights associated with EU Citizenship', which would justify 'personal circumstances scrutiny' under the Treaties 'before it can validly take effect'. ${ }^{114}$

Coming back to the scenario that is the focus of this paper, the issue of the continuing enjoyment, by (some of) the newly created state entity's nationals, of (some of) the benefits attaching to the nationality of the rump Member State could, of course, be the object of a bilateral agreement between the rump Member State and the seceding State entity. However, such a bilateral agreement could never have the effect of offering to all nationals of the seceding state entity the continuing enjoyment of rights arising under EU citizenship (eg through conferral to them of the rump Member State's nationality) if the impact of secession is not to be negated. The following question therefore arises: would it be legitimate for the nationals of a newly created state entity to expect to be able to rely automatically, in their capacity as (former) EU citizens, on (some of) the constitutional attributes ${ }^{115}$ and/or rights of 'elevated' importance ${ }^{116}$ attaching to EU Citizenship, ${ }^{117}$ or to expect that their former status is, at least, taken into account, in the interim period between secession and EU accession, to facilitate their enjoyment of the rights attaching to EU citizenship?

What is worth noting from the outset is that there are three fundamental differences between the scenario in Rottmann and the secession scenario that is the focus of this paper. The first difference is that, applied to a secession scenario, the proportionality test in Rottmann would take on a collective dimension. While there is no reason, whether in logic or in law, why the withdrawal, through a sovereign act, of EU Citizenship rights affecting an entire collectivity should not be a matter of at least equal supranational interest to the withdrawal

113 In his opinion in Rottmann, Advocate General Maduro opined that, '[A]ny attempt at an answer presupposes a sound understanding of the relationship between the nationality of a Member State and Union citizenship. These are two concepts which are both inextricably linked and independent [fn omitted]. Union citizenship assumes nationality of a Member State but it is also a legal and political concept independent of that of nationality' (para. 23). Also see Kochenov (n 27) 203.

114 See M Dougan, 'Some Comment on Rottmann and the 'Personal Circumstances' Assessment in the Union Citizenship Case Law' in J Shaw (ed.) 'Has the ECJ Challenged Member State Sovereignty in Nationality Law?', EUI Working Papers, RSCAS 2011/62, 17.

115 As set out inter alia in Kadi (n 108) paras 284-6, 303-6, 317, and 322.

116 Golynker (n 105) 19.

117 Given the current status of EU Citizenship, reliance on it may in any event be less beneficial to a party seeking to maintain access to certain rights or benefits compared to reliance on another economic status (see Craig and De Bùrca (n 89) 847). One may, for instance, take the example of an EU citizen who has acquired a right of permanent residence in another Member State prior to secession affecting its territory, of the autonomous economic rights derived from Articles 20 and 21 TFEU, and of the political rights granted under Articles 22 to 25 TFEU (see Craig and De Bùrca (n 89), 848-50). 
of the rights of particular individuals, ${ }^{118}$ the proportionality exercise would clearly differ in a secession scenario, by involving a balancing act between national sovereignty, on the one hand (expressed through a deliberate act of secession, no less), and the collective interest of individuals on the other, to determine where the public interest lies. A second difference is that, in a secession scenario, the proportionality test would not be applied against the background of the adverse consequences of statelessness: in this respect, the proportionality test would be less demanding, hence easier for the national authorities to satisfy. A third difference is that, in Rottmann, the applicant's claim was against the Member State, and its decision to strip the applicant of his nationality, whereas in a secession scenario the claim would presumably (also) lie against the EU. These differences would appear to preclude a mutatis mutandis application of Rottmann to the secession scenario that is the focus of this paper.

To help establish what the extent of the legitimate expectations of the nationals of a newly created state entity might be, and whether the need to protect the enjoyment of rights associated with EU Citizenship could provide the basis for a claim to the continuing enjoyment ratione personae of certain rights by the nationals of a newly created state entity despite the absence of any right of automatic accession of the seceding state entity to the EU, it is useful to refer to the practice on the protection of fundamental human rights under the European Convention on Human Rights (the 'ECHR' or 'the Convention') in cases of secession. Ruling on the basis of the 'practical requirements' of Article $46 \mathrm{ECHR}$, and of the 'principle that fundamental rights protected by international human rights treaties should indeed belong to individuals living in the territory of the State party concerned, notwithstanding its subsequent dissolution or succession (emphasis added)..., the European Court of Human Rights (EctHR) has found that the Convention should be deemed 'as having continuously been in force' in Montenegro despite its independence from Serbia and during the time span until it joined the Council of Europe. ${ }^{119}$ For the purpose of a comparative analysis, and in so far as membership of international organizations, on the one hand, and fundamental rights protection, on the other, are concerned, it is worth recalling that membership of the Council of Europe and of the Convention are separate issues. However, it remains the case that no state can become a member of the Council of Europe without also becoming a signatory to the ECHR. This should be read in conjunction with the ECtHR's

\footnotetext{
118 See A O'Neill, 'A quarrel in a faraway country? Scotland, Independence and the EU', available at <http://eutopialaw.com/2011/11/14/685> last accessed on 26 August 2013.

119 Bijelic v Montenegro and Serbia (Application 11890/05, 28 April 2009, ECtHR), paras 67-9; also see Crawford and Boyle (n 15) 95-8. The case was originally brought against SerbiaMontenegro and then against Montenegro and Serbia separately. Montenegro joined the Council of Europe as a new state on 11 May 2007, in accordance with Art. 4 of the Statute of the Council of Europe, whereas the Republic of Serbia continued the membership of Serbia and Montenegro in the Council of Europe.
} 
finding, above, that a state can become a party to the ECHR through succession (although there is no express provision in the Convention to that effect), resulting in the continuous application of the Convention's provisions pending an invitation for the seceding state entity to join the Council of Europe. ${ }^{120}$ Without prejudice to the insights that the above comparison provides, the substantial differences in the accession procedure and membership between the Council of Europe and the $\mathrm{EU}^{121}$ would seem to preclude the drawing of any direct analogy of relevance to the scenario under consideration in this paper.

The example of the Baltic States is also instructive (although theirs was neither a case of state succession nor secession but, rather, of state continuity). ${ }^{122}$ In the case of the Baltic States, state continuity entailed a restoration of pre-war citizenship legislation, which had been 'suspended' during the period of Soviet rule. In addition to those who fulfilled the requirements of the pre-war citizenship legislation, 'automatic' citizenship was only granted to a limited number of other residents (the legislation in question was later amended in view of EU accession, but only to an extent: citizenship rights did not extend fully to Russian-speaking and other 'stateless' residents of these countries). ${ }^{123}$ As a matter of international law, the better view is that the principle of continuity does not imply a right of citizenship for immigrant population, hence the existence of 'non-citizens' in the Baltic States. ${ }^{124,125}$ However limited its application to the scenario under consideration in this paper and to our examination of the possibility of a claim to the continuing application of EU citizenship rights for the benefit of the inhabitants of a seceding state entity, the example of the Baltic States confirms that, 'there is no uniform set of rules regarding the granting of citizenship after the restoration of independence'. ${ }^{126}$

In conclusion, it appears that, in a secession scenario, the enjoyment by the inhabitants of the newly created state entity of EU Citizenship rights cannot be

120 See Crawford and Boyle (n 15) 95-8.

${ }^{121}$ Membership of the Council of Europe is upon invitation by the Committee of Ministers (Art. 4 of the Statute of the Council of Europe) following satisfaction of the conditions set out in Art. 3 of the Statute. It is, therefore, quite different from accession to the EU, on the basis of Art. 49 TEU (which is a process based on conditionality and negotiations).

122 The Baltic States were recognized on the basis of State continuity as the Soviet period of occupation was deemed illegal and as such was null and void; see Van Elsuwege (n 44) 59-85.

123 Ibid 69-79.

124 Ibid 75.

125 With EU accession, the status quo has nevertheless become harder to reconcile with the protection of fundamental principles of non-discrimination, free movement and EU citizenship under the EU Treaties, as interpreted by the Court in its case law. In this regard see, for instance, P Van Elsuwege, 'Russian-speaking Minorities in Estonia and Latvia: Problems of Integration at the Threshold of the EU', ECMI Working Papers, 20/2004, 53-7; see also Van Elsuwege (n 44) 262-8 on the impact of the EU accession process on the language legislation of the Baltic States. See more generally F De Varennes, Language, Minorities and Human Rights (Kluwer, The Netherlands 1996), 246.

126 As quoted in Van Elsuwege (n 44), 78 (fn 361); see alsoibid 269-88. 
automatic. The absence of an automatic right to EU Citizenship (the existence of which would imply the continuing enjoyment of the rights deriving therefrom), does not necessarily mean that, in the interim period between secession and accession to the EU, the nationals of a newly created state entity would not have a legitimate expectation to the survival of certain aspects of their former EU Citizenship rights. What it does, however, mean is that these expectations can only be given effect through negotiations, involving the rump Member State and other EU Member States, on the one hand, and the seceding state entity, on the other, informed by the need to avert some of the adverse consequences, for individuals, of the act of secession.

\section{B. PIL considerations}

Although the EU constitutes a 'new legal order of international law' with its own internal rules, ${ }^{127}$ the Treaties on which the EU is founded have been negotiated and concluded in accordance with the general principles of PIL, thereby giving rise to rights and obligations for the participating Member States enforceable (also) as a matter of PIL. For the reasons touched on later in this section, there is a limit to the analogies that can be drawn between the EU and a regular international organization (and, by extension, to the utility of the lessons drawn from PIL with regard to the normative treatment of secession within the EU). However, for the sake of completeness, it is necessary to examine the normative treatment of the scenario that is the focus of this paper not only from the perspective of EU law but, also, from that of PIL.

\section{(i) Introductory remarks}

The questions addressed in this section are, essentially, questions of 'state continuity' and 'state succession', 128 areas of great uncertainty and controversy. ${ }^{129}$

127 Case 26/62, Van Gend en Loos v Nederlandse Administratie des Belastingen [1963] ECR 3: '[t]he European Economic Community constitutes a new legal order of international law for benefit of which the states have limited their sovereign rights, albeit within limited fields, and the subject of which comprise not only the Member States but also their nationals'.

128 Both the 1978 Vienna Convention on Succession of States in respect of Treaties (United Nations, Treaty Series, vol. 1946, 3) and the 1983 Vienna Convention on the Succession of States in respect of State Property, Archives and Debts (not yet in force at the time of writing) define 'succession of States' as the 'replacement of one State by another in the responsibility for the international relations of territory' (see Art. 2(1) (b) and Art. 2(1) (a), respectively).

129 See the comment of Germany's Federal Supreme Court in the Espionage Protection Case that, 'the problem of State succession is one of the most disputed areas of international law' (Case No. 2 BG 38/91, 94 International Law Reports 68, 77-8). In this regard, also see Brownlie (n 20), 650; MP de Brichambaut et al, Leçons de droit international public (Dalloz, Paris 2002) 68; and MCR Craven, 'The Problem of State Succession and the Identity of States under International Law' (1998) 9 European Journal of International Law 142, 143-4. The authors acknowledge that the concepts of state continuity and succession are not amenable to precise definition. 
Whether in a concrete factual situation one is faced with a process of secession, as opposed to dissolution, ${ }^{130}$ ie whether an existing state co-exists with a new state entity, even if only as a rump State, or the predecessor state has simply ceased to exist, is a question to which the answer depends mainly on considerations of customary international law (rather than treaty law), drawn from state practice and opinio juris (including the opinions of international organizations). Neither of the two international conventions addressing issues relevant to state succession appears to reflect state practice in this area. ${ }^{131}$ Indeed, the relevant state practice is far from uniform or unambiguous, to the point that settled legal rules have yet to emerge, even as a matter of customary law (let alone treaty law). It nevertheless stands to reason that there should be at least a presumption of state continuity where the rump state involves what may be regarded as fundamentally the same territorial and governmental unit, despite the diminution in its territory and population resulting from the political events lying at the roots of its mutation. ${ }^{132}$ This presumption of continuity would prima facie also be consistent with the fulfilment of the PIL criteria for statehood, as a condition precedent to recognition (although some of the confusion in this area would ultimately appear to arise from conflating the concepts of statehood and recognition with those of continuity and succession). ${ }^{133}$

\section{(ii) Basic propositions on state continuity and succession drawn from PIL}

Despite the absence of clearly settled legal rules, there is something of a consensus around three basic propositions of PIL regarding state continuity and succession.

The first is that where the political events giving rise to mutations affecting the territory, population, or system of government of a state do not result in the extinction of that state, the rump state's rights and obligations remain unaffected (including those arising under treaties or attaching to a state's membership of international organizations). ${ }^{134}$ It follows that, in cases of secession within the meaning of this paper, the coming into being of one or more seceding state entities does not normally affect the existence of the rump state in the international stage, nor does it raise issues of state continuity and succession. ${ }^{135}$

${ }^{130}$ As a commentator has aptly observed, '[I]n most cases, it is extremely difficult to distinguish properly between the two classes of case, as, for instance, between a case of multiple succession and one of dismemberment... factually speaking, the processes are similar' (Craven (n 129), 153).

131 The reference is to the 1978 and to the 1983 Vienna Conventions (see note 128), which commentators consider to deviate from and to only partially reflect state practice (see, for instance, P-M Dupuy and Y Kerbrat, Droit international public (Dalloz, Paris 2010) 73-74; Brownlie (n 20) 653 and 662; Brichambaut et al (n 129) 69; Shaw (n 17) 959; and M. Dixon, Textbook on International Law (3rd edn, Blackstone, London 1996) 73.

132 Crawford and Boyle (n 15) 77-8.

133 The point is aptly made in Craven (n 129), especially 160-1.

134 See, for instance, Crawford and Boyle (n 15), 78-81; Shaw (n 17) 974; and Happold (n 5) 22-8.

135 This proposition is borne out by the examples of Singapore's separation from Malaysia, in 1965, and West Pakistan's separation from Pakistan, in 1972 (in both cases, the rump states retained their 
The second proposition is that, where a new state emerges, this 'will commence international life free from the treaty rights and obligations applicable to its former sovereign', 136 and will 'not [be] bound by the treaties of the predecessor sovereign by virtue of a principle of state succession'. ${ }^{137}$ The common sense attraction of this proposition is irresistible: a new state that was not party to a treaty cannot be bound by it, nor can other parties to a treaty be bound to accept a new party in their midst. ${ }^{138}$ This proposition is also broadly consistent with Article 16 of the 1978 Vienna Convention on Succession of States in respect of Treaties, according to which new states start with a 'clean slate', even though they may expressly agree to be bound by treaties made on behalf of their territory by the former sovereign. The 'clean slate' rule is borne out by the example of the Baltic States, which, in regaining their independence in 1991, did not consider themselves as successor states to the Union of Soviet Socialist Republics (USSR), refusing to be bound by any of the treaties concluded by the latter. ${ }^{139}$ Interestingly, a different solution applies in cases of separation, where the presumption is one of continuity of treaties and membership of international organizations with regard to each constituent part of the defunct union. ${ }^{140}$ This proposition is borne out by the example of the demise of Czechoslovakia, where the Czech Republic and Slovakia declared themselves as successor states, stating their willingness to take over the international obligations of former Czechoslovakia. ${ }^{141}$

The third and final proposition is that, in cases of mutations affecting the territory, population and, possibly, also the system of government of a state, the success of claims to continuity of treaties and membership of international organizations crucially depends on the reactions of third parties and, in particular, on the support of the international community or, inversely, its opposition to such claims. ${ }^{142}$ In the words of a commentator, 'the law of state succession is ultimately self-regarding - the question whether a new state is bound by particular conventional norms of succession is contingent upon a recognition that it has, indeed, succeeded to those norms'. ${ }^{143}$ This proposition is readily borne out

international identity, whereas Singapore and Bangladesh were eventually admitted by the United Nations (UN) as new states).

136 Shaw (n 17) 974 and fn 106.

137 Brownlie (n 20), 661.

138 Ibid 661.

139 Whether or not the example of the Baltic States is one of secession or, instead, of dissolution (precluding any claim to succession) is not entirely clear (in this regard see Shaw (n 17) 961-2; Brichambaut et al (n 129) 71; and Malanczuk (n 20) 165-6).

${ }_{140}$ The above propositions are broadly consistent with the provisions of the 1978 Vienna Convention on Succession of States in respect of Treaties (see, in particular, Arts 34 and 35).

141 On the Czechoslovak example see, generally, Schweisfurth (n 17) 339; and Malanczuk (n 20) 167.

142 This point is made, amongst others, in Dupuy and Kerbrat (n 131) 74; Shaw (n 17) 970-1; and Brownlie (n 20) especially 661-5.

143 Craven (n 129), 151. 
by a comparison between the examples of the demise of the USSR and Czechoslovakia, on the one hand, and the SFRY on the other. In the case of the USSR and Czechoslovakia, there was ample support by the international community to back the pretentions of Russia, the Czech Republic, and Slovakia to being treated as successor states. The backing of the international community to the pretentions of the Federal Republic of Yugoslavia (FRY, consisting of Serbia and Montenegro) to continuing the SFRY was manifestly lacking, hence the UN Security Council's rejection of the FRY's claims to continuity, ${ }^{144}$ echoed by that of the Conference for Peace in Yugoslavia Arbitration Commission ('the Badinter Commission'). ${ }^{145}$

\section{(iii) State continuity and succession in the EU context: what lessons from PIL?}

As will have become apparent from the preceding account, in PIL the (difficult) question of state succession - ie whether or not one state has replaced another in the responsibility for the international relations of a territory-is preceded by that of continuity. ${ }^{146}$ In other words, if a state is deemed to continue to exist, despite changes to its territory and population (and, possibly, also to its system of government) the question of its succession by any newly created state entity to particular rights and obligations (including those resulting from its participation in international organizations) does not arise in the first place. In a (genuine) secession scenario, the departure of one (or more) of the territorial components of a state will not bring about the predecessor state's dissolution: this will continue to exist as a rump state, carrying forward its legal personality, remaining bound by any international treaties to which it had acceded prior to secession, and retaining its place in any international organizations of which it had been a member at the time of secession. For its part, the newly created state entity will be a new subject of PIL. As a result, the newly created state entity will not automatically step into the rights and obligations of the rump state (without prejudice to its right to adopt freely an existing treaty, as per Article 16 of the 1978 Vienna Convention on Succession of States in respect of Treaties). ${ }^{147}$

${ }_{144}$ UN Doc. S/Res 757, 30 May 1992; UN Doc. S/Res 777 (1992).

145 In its Opinion No. 10, dated July 1992, the Badinter Commission found that, 'the FRY (Serbia and Montenegro) is a new state which cannot be considered the sole successor to the SFRY' (para. 5).

146 See Crawford and Boyle (n 15) 72; Weller (n 12) 2-3; and Brownlie (n 20) 661.

147 Cases of consensual secession would, admittedly, represent something of a 'grey area' between secession and dissolution, since, in practical terms, they would be indistinguishable from cases of negotiated dissolution (exemplified by the demise of Czechoslovakia), where questions of state continuity and succession do arise. Such cases would, nevertheless, represent something of a logical aberration: secession is, by definition, non-consensual (even if it does not entail the use of armed force), and it is readily distinguishable from dissolution, at least in terms of its concrete effects: political events giving rise to a mere change in a state's territorial status are, normally, consistent with a secession scenario, while events leading to the disappearance of a state and its replacement by two or more new states are, normally, consistent with a dissolution or a separation scenario (depending on how consensual the underlying divorce was). 
It follows from the above that, in a genuine secession scenario, the question of the automatic accession of a newly created state entity to the EU, as an incident of 'state succession', does not arise as a matter of PIL. That question would only arise where an existing EU Member State would cease to exist, with its territory and population divided up (even if unequally) between two or more new state entities, recognized as such by other states, with all the attendant implications in terms of their membership of international organizations and their obligations under existing treaties. ${ }^{148}$ It would also follow from the PIL propositions set out above that, in a secession scenario, accession would, a priori, not be automatic, with pre-accession negotiations being necessary, in line with Article 49 TEU. ${ }^{149}$

\section{(iv) Concluding remarks: the relevance of PIL to State continuity and secession in the EU context}

Without prejudice to the preceding observations, it is conceded that there are limits to the utility of the analogies drawn, in this context, from PIL and to the latter's suitability as a framework of reference for the assessment of the EUspecific treatment of secession. Whilst it is not the aim of this paper to address, in any detail, the controversial question of the legal nature of the EU and its relationship to PIL, ${ }^{150}$ suffice it to make the following general observations on the relevance of PIL to state continuity, specifically in the context of the EU.

In their original conception, the EC were akin to a regular international organization, premised on Treaties that were negotiated in accordance with, and legally binding under, PIL. ${ }^{151}$ However, the sui generis nature of the EC

148 Political circles favourable to Scotland's potential secession have advanced the argument that Scotland would not be a new state, but would instead carry forward the legal personality it presently shares with the rest of the UK. Alternatively, both Scotland and the rump UK would be 'new states', and would both need to apply for EU membership should they wish to, similar to the case of Czechoslovakia (in this regard see Weller (n 12) 1-2; and Crawford and Boyle (n 15) 83-7). Similar arguments have been advanced with regard to a potential secession of Catalonia from Spain (in this regard see Happold (n 12) 1-2).

149 Taking into account the specificities of the dissolution scenario, an 'accelerated EU accession' procedure might be conceivable, subject to the consent of all existing EU Member States and to their willingness to amend the Treaties, in line with Article $48 \mathrm{TEU}$, to render legally possible an accelerated EU accession procedure specifically applicable to cases of dissolution.

150 This issue is discussed in more detail inter alia in Athanassiou (n 2) 15-18; M Lickova, 'European Exceptionalism in International Law' (2008) 19 European Journal of International Law 463; and De Witte, 'Retour à Costa_La primauté du droit communautaire à la lumière du droit international' (1984) 20 Revue trimestrielle de droit européen 425.

151 See, for instance, J F McMahon, 'The Court of the European Communities: Judicial Interpretation and International Organisation' (1961) 37 British Yearbook of International Law 320,329 (" $\mathrm{t}$ ] he origins, powers and objectives of the three Communities are all to be found in international treaties'); and JHH Weiler and UR Haltern, 'The Autonomy of the Community Legal Order-Through the Looking Glass' (1996) 37 Harvard International Law Journal 411, 419 (' $[\mathrm{t}]$ here is no doubt that the European legal order started its life as an international organisation in the traditional sense, even if it had some unique features from its inception'). Another commentator has treated Community law as a successful emanation of PIL (C Leben, 'Hans Kelsen and the Advancement of International Law’ (1998) 9 European Journal of International Law 287, 298). 
was to be recognized early on, in the jurisprudence of the CJEU, first in Van Gend en Loos (where the Court inter alia stated that EC law was capable of having direct effect, ie of creating legal rights enforceable by both natural and legal persons before domestic courts, independently of national law $)^{152}$ and, soon thereafter, in Costa $v$ ENEL (where the Court introduced the doctrine of the supremacy of EC over national law). ${ }^{153}$ In both cases, the main rationale for the Court's rulings was that the EC were conceived as a 'new' legal order, creating not just rights and obligations between Member States but, also, for those within their jurisdiction, including natural and legal persons or administrative agencies. The differences between the EC and a traditional international organization were reflected in the existence of an assembly and other institutional organs, whose presence entailed a certain role for social actors, in the existence of a nexus between Member State and EC law, expressed most visibly in the preliminary rulings procedure, and in the reference, in the preambles of the Treaties, to the 'peoples of Europe'. ${ }^{154}$

These two seminal rulings of the Court were sufficient to elevate the EC from a regular intergovernmental organization to a more sui generis legal status, with certain attributes similar to those encountered in federal states. The EU is, perhaps, unique amongst international organizations in sharing a number of traits typical both of classical inter-state cooperation organizations and federal or confederate-type structures. The distribution of competences between the EU and the Member States (Article 2 TFEU), underscored by the principle of sincere cooperation (Article 4 TFEU), the judicially declared irrevocability of the transfer of sovereignty from the Member States to the EU, the EU's system of autonomous regulatory production, the institutional structure of the EU, as well as the EU's legal capacity and international representation powers are,

152 See Case 26/62, Van Gend en Loos v Nederlandse Administratie des Belastingen [1963] ECR 3, where the Court stated that, '[I]ndependently of the legislation of Member States, Community law... not only imposes obligations on individuals but is also intended to confer upon them rights which become part of their legal heritage. These rights arise not only where they are expressly granted by the Treaty, but also by reason of obligations which the Treaty imposes in a clearly defined way upon individuals as well as upon the Member States and upon the Institutions of the Community.'

153 See Case 6/64 Costa v ENEL [1964] ECR 585, where the Court stated that, '[B]y contrast with ordinary international treaties the EEC Treaty has created its own legal system which, on the entry into force of the Treaty, became an integral part of the legal systems of the Member States and which their courts are bound to apply. ... By creating a Community of unlimited duration, having its own institutions, its own personality, its own legal capacity and capacity of representation on the international plain and, more particularly, real powers stemming from a limitation of sovereignty or a transfer of powers from the States to the Community, the Member States have limited their sovereign rights and have thus created a body of law which binds both their nationals and themselves.... The transfer by the States from their domestic legal system to the Community legal system of the rights and obligations arising under the Treaty carries with it a permanent limitation of their sovereign rights'.

154 See, generally, J Klabbers, 'Presumptive Personality: The European Union in International Law', in Martti Koskenniemi (ed.) International Law Aspects of the European Union (Martinus Nijhoff, The Netherlands 1998) 231-53. 
arguably, more reminiscent of a federal (or 'parafederal') structure, than they are of a regular international organization. ${ }^{155}$ The 'robustly dualist' ${ }^{156}$ reasoning of the Court in $\mathrm{Kadi}^{157}$ (where the Court refused to allow a UN Security Council resolution to enjoy primacy over EU law) has strongly emphasized the separateness and autonomy of the EU from other legal systems and from the international legal order, in particular.

If the EU has, gradually, lost its moorings in PIL, and if it can no longer meaningfully be regarded as a regular international organization (despite having originally been a creature of international law $)^{158}$ there is, decidedly, a limit to the utility of the lessons drawn from PIL with regard to the treatment and consequences of secession in the context of the EU.

\section{II. 'Internal EU enlargement?': The EMU perspective}

It has been argued in Part I of this paper that there is no automatic right of accession to the EU upon secession from an EU Member State. Given that EMU is a 'subset of the EU', it would logically follow that there can also be no automatic right of accession to the single currency upon secession from an EMU Member State. ${ }^{159}$ Part II explores the issue of the existence, or otherwise, of an automatic right of accession to EMU for seceding State entities that were formerly part of an existing euro area Member State (Section A); it then inquires into the relevance, for cases of secession, of precedents involving territorial entities, which, while having undergone changes in their status as part of an internal territorial modification process, and 'withdrawn' from the EU, have nevertheless retained the euro as their (sole) legal tender (Section B); finally, it outlines the legal implications of EMU accession, as well as the EMU accession

155 Arguments to this effect have been advanced, inter alia, by Harhoff (n 5) 29-30; J Weiler, 'Alternatives to Withdrawal from an International Organization: The Case of the EEC' (1985) 20 Israel Law Review 282, 285-6; Louis, The Community Legal Order (European Commission, Brussels, 1993) 11-18 and 75-77; Friel (n 2) 412; Athanassiou (n 2) 9-18; and Matas et al (n 33) 17-27.

${ }^{156}$ G De Búrca, 'The European Court of Justice and the International Legal Order after Kadi' (2010) 51(1) Harvard International Law Journal 1, 23.

157 See n 108. For an assessment of the Court's ruling in Kadi see C Tomuschat, 'The Kadi Case: What Relationship is there between the Universal Legal Order under the Auspices of the United Nations and the EU Legal Order?' [2009] Yearbook of European Law 654; De Búrca (n 156); and J Kokott and C Sobotta, 'The Kadi Case-Constitutional Core Values and International LawFinding the Balance?' (2012) 23 European Journal of International Law 1015.

158 The point is not entirely uncontroversial: see, for instance, Moorhead, who has cogently argued that the EU legal order is, essentially, one of international law, and that the supremacy of EU law obligations over domestic law ones is merely based on the principle of the supremacy of international over national law (T Moorhead 'European Union Law as International Law' (2012) 5 European Journal of Legal Studies 126).

159 Athanassiou (n 2) 29. For an earlier, pre-Lisbon Treaty assessment of the possible withdrawal of Member States from the EU, see H de Waele, 'The European Union on the Road to a new Legal Order-The Changing Legality of Member State Withdrawal' (2004-2005) Tilburg Foreign Law Review 12, 169. 
criteria and procedure (Section C). The main conclusions drawn from our analysis are summarized at the end of this Part (Section D).

A few points of terminology are apposite, before turning to the substance of our analysis. As used in this Part, the term 'euro area' denotes those EU Member States where the euro has been formally adopted, following the procedure prescribed in the Treaty, and where monetary policy is conducted under the responsibility of the Governing Council of the European Central Bank (ECB). The term 'ESCB' denotes the ECB and the national central banks (NCBs) of all EU Member States (including those where the single currency has yet to be formally adopted), while the term 'Eurosystem' refers to the monetary authority of the euro area comprising the ECB, the NCBs of the EMU-participating Member States, and the collective decision-making bodies through which the single monetary policy is defined and implemented. The terms 'euro area Member State' and 'EMU-participating Member State' are used interchangeably. The terms 'euro' and 'single currency' are used as synonyms, and the same is true of the terms 'accession to the euro area' and 'adoption of the single currency'.

\section{A. Separation from an EMU-participating Member State-what rights of accession to EMU?}

The Treaties are silent on the possibility of an internal enlargement of EMU. Moreover, there is, to date, no precedent of secession from an EMUparticipating Member State, nor is there any precedent of part of an EMU Member State having attained its full independence and, yet, retained the single currency as its legal tender. Absent any precedent, some might be tempted to argue that it would be artificial for a state entity resulting from secession from an EMU Member State to have to 're-apply' for admission to EMU, when the euro was already in circulation in its territory, as sole legal tender. Despite its common-sense attraction, the above proposition conflates a de facto situation with the Treaties' very specific understanding of the concept of the (regulated) adoption of the single currency. It is for that reason, legally objectionable. The remainder of this section will examine the reasons why.

As explained later in this Part (Section C), the first stage towards EMU accession is EU accession. It follows that the prior use of the single currency in the territory of a state entity resulting from secession from a euro area Member State does not, ipso facto, provide any legal basis for a Member State's automatic accession to EMU, nor does it afford any legitimate expectation of the continued use of the single currency, based on past practice or historical considerations: a new state entity would first need to accede to the EU before introducing the single currency. Leaving the above considerations aside, the EMU accession procedure prescribed in the Treaty is silent on the possibility of deviations for the benefit of States resulting from secession from 
EMU-participating Member States. One way to interpret the silence of the Treaties is that the possibility of secession was never envisaged by the fathers of the Treaties, who have not specifically catered for it for that reason, rather than on account of any principled objection to a 'customized' (whether 'simplified' or 'accelerated') EMU accession procedure, reserved for deserving cases. Another way to interpret the silence of the Treaties on the possibility of an internal EMU enlargement is as an expression of a clear institutional opposition to any deviation from the prescribed EMU accession route: any such deviation, the argument runs, would contradict the letter of the Treaties and negate the fundamental economic rationale underlying EMU.

The second of the above two interpretations is clearly supported by the letter of the Treaties. De lege lata there is no legal basis for a differentiated EMU accession procedure. EMU, one should not forget, is a rules-based system: it is of the essence to its continuing existence (and to its economic rationale) that the same objective accession criteria apply to all candidates alike. As explained later in this Part (Section C), whether or not these criteria are fulfilled in an individual case is a function of a detailed assessment by the Commission and the ECB. This assessment cannot meaningfully be substituted with a mere declaration of compliance, motivated by reference to factual considerations. The requirement for an assessment applies equally to all candidates, however an aspirant Member State may have come into being. Besides, from a purely practical perspective, it is difficult to see how any of the EMU accession criteria can be relaxed. ${ }^{160}$ Leaving aside obvious equal treatment considerations (to which there is also a substantive angle, as the on-going European sovereign debt crisis has shown $)^{161}$ neither the economic nor the legal convergence criteria are amenable to automatic fulfilment: positive action needs to be taken by the candidate country (in terms of fiscal and budgetary efforts, complemented by extensive legislative amendments), followed by an assessment of the adequacy of such action by the Commission and the ECB, and by a decision of the European Council to lift the candidate's derogation. No circumvention of the existing EMU accession procedures would be legally permissible without a prior amendment to the Treaties, following the simplified revision procedure of Article 48 TEU (which, as the reader will recall, calls for a unanimous decision of the European Council to adopt the proposed Treaty amendment).

Would the above necessarily lead to the conclusion that the single currency would unavoidably have to be withdrawn as legal tender from the territory of a state entity resulting from secession from an EMU-participating Member State, and replaced by a new (and possibly temporary) national currency? The regulated adoption of the single currency, understood as a Member State's formal

160 The one possible exception is that of the two-year ERM-II waiting period, which could be shortened, but only subject to a prior amendment to the Treaties, to that effect.

161 The sovereign debt crisis has confirmed the importance of the institutional accession procedure, prescribed in the Treaties, to ensure that only deserving candidates accede to EMU. 
participation in EMU, within the meaning of the Treaties ${ }^{162}$ is to be distinguished from its (full) 'euroization', defined as the sole use of the euro as legal tender, in conjunction with the parallel abolition of its domestic currency but without fixing, consensually, the irrevocable conversion rate of the (former) domestic currency vis-à-vis the euro. ${ }^{163}$ There are two distinct 'euroization' possibilities, the unilateral and the consensual. The EU's negative views on unilateral euroization by candidates for EU accession and Member States with a derogation are well established. ${ }^{164}$ On the unilateral use of the euro by third countries (including, by implication, state entities resulting from secession) there is no clearly formulated EU position, despite the fact that there are examples of third countries or entities where the euro is used as (the sole and official) legal tender (eg Montenegro and Kosovo and, previously, also Andorra). What is, in any event, clear is that third countries cannot unilaterally adopt the euro formally, since there is no procedure in the Treaties for the Council's approval of the adoption of the single currency by third countries. While State entities resulting from secession from an EMU-participating Member State would not have a domestic currency that they could, strictly speaking, 'euroize' unilaterally, the Commission's and the ECB's ${ }^{165}$ position on unilateral euroization by

162 The formal participation of a Member State in EMU is inter alia reflected in the contribution of the Governor of its NCB, as a fully-fledged Member of the ECB Governing Council, in the definition of the single monetary policy, in the issuance of euro banknotes and coins by its NCB, or in its sharing of the resulting seignorage income.

163 S Levasseur, 'Why not Euroisation?' (2004) 91(5) Revue de l'OFCE 121-155, 123.

164 "Any unilateral adoption of the single currency by means of "euroisation" would run counter to the underlying economic reasoning of EMU in the Treaty, which foresees the eventual adoption of the euro as the endpoint of a structured convergence process within a multilateral framework. Therefore, unilateral 'euroisation' would not be a way to circumvent the stages foreseen by the Treaty for the adoption of the euro' (EC DGII, 'Enlargement Argumentaire', Enlargement Papers No 5, 2001, 21). For additional references, see Council Reply to Written Question E-3950/00 by Sylvia-Yvonne Kaufmann (GUE/NGL) to the Council, 2001/C 235 E/041, available at: <http://eur-lex.europa.eu/LexUriServ/LexUriServ.do?uri=OJ:C:2001:235E:0037:0038:EN:PDF> last accessed on 31 August 2013; Policy Position of the Governing Council of the European Central Bank on Exchange Rate Issues Relating to the Acceding Countries, available at: < http://www.ecb. int/pub/pdf/other/policyaccexchangerateen.pdf > last accessed on 31 August 2013; and Commission Staff Working Document Analytical Report accompanying the Communication from The Commission to the European Parliament and the Council, Commission Opinion on Montenegro's application for membership of the European Union, Brussels, 9 November 2010 SEC(2010) 1334 available at: <http://ec.europa.eu/enlargement/pdf/key_documents/2010/pack age/mn_rapport_2010_en.pdf $>$ last accessed on 31 August 2013.

165 The ECB's position on unilateral euroisation is summarised in the following statement: 'the ECB ... would neither encourage nor facilitate such a move. Countries which unilaterally introduce the euro would do so in their responsibility and at their own risk, without committing the EU or the ECB. The ECB would thus pursue a policy of non-engagement and non-support towards these countries' (J Stark, 'The adoption of the euro: principles, procedures and criteria', Speech delivered to the Icelandic Chamber of Commerce, Reykjavik, 13 February 2008, available at: <http://www. ecb.int/press/key/date/2008/html/sp080213.en.html > last accessed on 31 August 2013). In the case of non-EU EEA Member States, the EEA Treaty provides for mandatory 'monetary cooperation', which is understood as prohibiting unilateral euroisation by non-EU EEA Member States. Prior agreement with the EU would be required. 
acceding countries (and Member States with a derogation) suggests that the policy stance of both EU institutions would almost certainly be negative also in their case. ${ }^{166}$ The economic and political costs of unilateral euroization would need to be weighed against its perceived benefits before a state entity resulting from secession from an EMU-participating Member State embarks on it in the aftermath of secession, faced with the practical difficulties of 'de-euroizing' its economy and introducing a new currency. ${ }^{167}$

While euroization would be highly controversial if carried out unilaterally by a state entity resulting from secession from an EMU-participating Member State, the same need not be true in a case of consensual euroization. Article 219(3) TFEU already provides for the possibility of concluding Monetary Agreements with third States or international organizations, ${ }^{168}$ and there are several examples of such agreements to date. ${ }^{169}$ Interestingly for the purposes of this paper, the rationale for the conclusion of the hitherto monetary agreements with the EU has been that all of the third States concerned had been using a legacy currency of the euro prior to the physical introduction of the single currency. ${ }^{170}$ Drawing on the extant examples, a Monetary Agreement with a newly created state entity would need to regulate, apart from the use of the euro as legal tender, (a) the obligation to protect the single currency against counterfeiting; (b) the conditions subject to which financial institutions operating in the territory of the seceding state entity could accede to interbank settlement and payments and securities settlement systems; (c) the obligation to adopt all appropriate measures with a view to implementing selected EU legal acts in the areas of banking and financial law; and (d) the option for the parties to terminate the agreement, upon notice. One key issue that such an agreement could not address in the case of a seceding state entity, absent a national currency amenable to a stricto sensu euroization, is that of the consensual fixing of the irrevocable conversion rate of the (former) domestic currency vis-à-vis

166 'From the point of view of equal treatment, it would be difficult to conceive that the EU would be more open towards euroisation by non-candidate countries than by candidate countries or Member States with a derogation' (ibid).

${ }^{167}$ In this regard see, for instance, A. Winkler et al., 'Official Dollarisation/Euroisation: Motives, Features and Policy Implications of Current Cases', ECB Occasional Paper Series No.11, February 2004, available at: < http://www.ecb.int/pub/pdf/scpops/ecbocp11.pdf > last accessed on 31 August 2013; and Levasseur (n 163).

168 Monetary agreements are to be entered into by the EU Council (representing the EU) and the relevant third State or international organisation. There is, however, a precedent of such an agreement having been entered into with an EU Member State, acting for the benefit of one of its overseas collectivities (see Part II, section B of this paper).

169 The reference is to the monetary agreements entered into with the Principalities of Andorra and Monaco, the Republic of San Marino, and the Vatican City State, and published in the Official Journal of the European Union.

${ }^{170}$ For an overview of the extant Monetary Agreements, see 'Monetary and Exchange Rate Arrangements of the Euro Area with Selected Third Countries and Territories', ECB Monthly Bulletin, April 2006, 87. 
the euro. ${ }^{171}$ Moreover, unlike in the case of the Monetary Agreements with the Principalities of Andorra and Monaco, the Republic of San Marino and the Vatican City State, an agreement entered into with a seceding state entity could obviously not authorize that entity to issue its own euro coins. ${ }^{172}$ Whilst unilateral euroization is not compatible with qualifying for EMU membership, the possibility of consensual euroization is one that newly created state entities may be tempted to explore. ${ }^{173}$ As in the case of unilateral euroization, the costs of consensual euroization would need to be assessed by the political establishment in a newly created state entity and explained to its public opinion.

\section{B. The relevance to the debate of cases of internal territorial modification processes: the example of Saint Barthélemy}

While there is no precedent of secession from an EMU-participating Member State, there is at least one recent example of an internal territorial modification process affecting an existing EMU Member State, which was not accompanied by withdrawal from circulation of the single currency from the part of its territory concerned by the modification process in question, despite the fact that the said territory ceased to fall within the territorial scope of application of the Treaties (and, by extension, also EMU). ${ }^{174}$ This section briefly examines the relevance of cases such as this to the secession debate and, in particular, the insights that these cases can provide on whether or not there is, in the event of secession, an automatic right of accession to (or, more properly, retention of) the single currency. What is worth noting from the outset is that there are limits to the analogies that can be drawn from the situation of territories/dependencies of

171 The practical reason accounting for the EU's opposition to euroisation outside the framework of the Treaties is that, in such a constellation, the entry exchange rate into EMU cannot be fixed in negotiation between the candidate and existing member countries (see W Buiter and C Grafe, 'Anchor, Float or Abandon Ship: Exchange Rate Regimes for the Accession Countries' (2002) Banca nazionale del lavoro quarterly review 55, 112-42). It has been argued that the 'agreed conversion rate requirement' could be met if euroisation were to occur 'as an agreed alternative to joining ERM II', with the EU authorities asked to approve the equivalent of the ERM II central rate (Kenen and Meade, 'Substance and Semantics in ERM II', Central Banking Journal, 25 May 2004, available at: <http://www.centralbanking.com/central-banking-journal/feature/2074664/substance-seman tics-erm-ii) $>$ last accessed on 31 August 2013.

172 In this regard, see ECB Opinion CON/2011/22 on a recommendation for a Council decision on the arrangements for the negotiation of a Monetary Agreement with the French Republic, acting for the benefit of the French overseas collectivity of Saint-Barthélemy, para. 2.

173 It has aptly been observed that, once Montenegro has joined the EU and become a euro area candidate, the EU institutions will, in any event, face the problem of what to do with a non-euro area country that has informally 'adopted' the euro as its national currency (see W Buiter, 'A wave of unilateral "euro-isations" would confound the EU's mean-spirited legal nitpickers', available at: <http://www.europesworld.org/NewEnglish/Home_old/Article/tabid/191/ArticleType/articleview/ArticleID/20412/language/en-US/Default.aspx $>$ last accessed on 31 August 2013).

${ }^{174}$ For a general and comprehensive appraisal of the EMU participation of the Member States' various overseas territories, see F Amtenbrink, 'EMU and the Overseas' in D Kochenov (ed.) EU Law of the Overseas: Outermost Regions, Associated Overseas Countries and Territories, Territories Sui Generis (Kluwer Law International, The Netherlands 2011). 
Member States, since these territories are, by definition overseas, and not a metropolitan part of the EU Member State to which they are attached. ${ }^{175}$

The island of Saint Barthélemy was, for several years, a French municipality (commune), falling under the jurisdiction of Guadeloupe, a French Département d'Outre Mer (hence, an integral part of French and EU territory). ${ }^{176}$ In a referendum held on 7 December 2003, the inhabitants of Saint Barthélemy sought their separation from the jurisdiction of Guadeloupe, and their transformation into a Communauté d'Outre Mer (an 'overseas collectivity'), in accordance with Article 74 of the French Constitution. This separation was accomplished in 2007. Under the terms of EU Council Decision 2010/718/EU of 29 October 2010 amending the status with regard to the European Union of the island of Saint Barthélemy, ${ }^{177}$ the island was to cease to be part of the EU as of 1 January 2012. Since that date, the island of Saint Barthélemy has ceased to be an outermost region (OR) of the EU, within the meaning of Article 349 TFEU, and has instead enjoyed, as of the same date, the status of an Overseas Country or Territory (OCT), within the meaning of Article 355(2) TFEU. According to the CJEU, 'in so far as they remain outside the ambit of the EEC Treaty, [OCTs] are, as regards the Community, in the same situation as non-member countries'. ${ }^{178}$ Interestingly, Saint Barthélemy is only the second Member State territory to have ever become separated from the EU (or the EC) after Greenland. ${ }^{179}$

Despite having, for all intents and purposes, 'withdrawn' from the EU, ${ }^{180}$ Saint Barthélemy has retained the euro as its sole currency. This has been accomplished by virtue of a Monetary Agreement on the basis of Article 219(3) TFEU, concluded between the French Republic (representing the island of Saint Barthélemy) and the EU Council (representing the EU). ${ }^{181}$ The Monetary Agreement in question is the first one to have been entered into not with a

175 Although the degree of autonomy of the overseas territories of Member States may greatly vary, the main difference with the scenario of state secession presented in this paper is that the former territories remain associated to a given EU Member State. The Treaties are applicable in theory to the entire territory of the Member States, including overseas or dependent territories and to any territories for whose external relations a Member State is responsible (Art. 355(3) TFEU), unless otherwise expressly provided in the Treaties. For an up-to-date and in-depth legal analysis of the status of territories associated to EU Member States, see Kochenov (ed.), EU law of the Overseas: Outermost Regions, Associated Overseas Countries and Territories, Territories Sui Generis (Kluwer Law International, The Netherlands, 2011).

176 On the status of overseas departments see Case 148/77, Hansen v Hauptzollamt Flensburg [1978] ECR 1787, para 10 and $\mathrm{n} 26$.

177 OJ L 325, 9 December 2010, 4.

178 Opinion 1/94 of the Court of 15 November 1994, on the Competence of the Community to conclude international agreements concerning services and the protection of intellectual propertyArt. 228 (6) of the EC Treaty, [1994] ECR I-5267, para. 17.

179 On Greenland's separation from Denmark and 'withdrawal' from the EC see nns 5 and 22.

180 The one exception is to do with the provisions of part IV of the TFEU, on the association of the OCTs with the EU.

181 OJ L 189, 20 July 2011, 3. 
third country (as in the case of the agreements with the Principalities of Andorra and Monaco, the Republic of San Marino, and the Vatican City State) but with an EU Member State (France), acting for the benefit of one of its OCTs. Moreover, unlike previous agreements, the Monetary Agreement in question does not provide for the possibility of issuing, locally, euro coins. Its main purpose is to ensure that directly applicable EU law (including ECB regulations and decisions) in the areas of monetary, banking, and financial legislation, as well as statistics, anti-money laundering, and euro counterfeiting apply to SaintBarthélemy.

While no doubt instructive, the example of Saint Barthélemy does not set a direct precedent for cases of secession, which one could draw on for guidance relevant to the situation of newly created state entities to assess the nature of their rights, if any, to continue using the single currency even after they have become separated from an EMU Member State. This is because OCTs are distinguishable from independent states in the following material respects: ${ }^{182}$ (i) whilst autonomous (or semi-autonomous), OCTs remain constitutionally linked to their home EU Member State; OCTs are, therefore, not independent countries, stricto sensu, despite being assimilable thereto, in some respects; ${ }^{183}$ (ii) as a result, OCTs lack the legal capacity to enter into international relations with States or organizations (their interests are, instead, represented by their respective home Member State); and (iii) the inhabitants of OCTs retain the nationality of their home Member State, although an OCT's territory does not qualify as part of the EU. ${ }^{184}$ Specifically as regards the EMU status of OCTs, the following considerations apply, which clearly distinguish their situation from that of independent countries (whether resulting from secession or not): (i) it is the NCB of an OCT's home euro area Member State (or another institution under the control of their home Member State) that is responsible for carrying out, in their territory, all tasks falling within the scope of competences of the Eurosystem; (ii) it is an OCT's home euro area Member State that is responsible for extending the application of all EMU-specific EU financial regulation to the OCT's territory, and for monitoring compliance therewith; and, last but not least, (iii) capital support for banks or other financial institutions operating within an OCT's territory, as well as emergency liquidity assistance (ELA) extended to such banks or other institutions are to be provided by the Treasury of the relevant OCT's home euro area Member State or by that Member State's $\mathrm{NCB}$, respectively. In contrast to an independent country, OCTs lack decisive powers in any of the aforementioned respects.

${ }^{182}$ For an account of the specificities of OCTs and an overview of the OCT Treaty Framework see F. Murray, The European Union and Member State Territories: A New Legal Framework Under the Treaties (Asser Press, The Hague 2012), especially Chapters 10 and 17.

183 See Opinion 1/94 of the Court (n 178).

${ }^{184}$ Murray (n 182), 93. 
The case of Saint Barthélemy is not an example of secession but, merely, one of internal territorial modification, which is to be distinguished from that of the creation, through secession from an EMU-participating Member State, of a new State. The specificities of OCTs, and their continuing attachment to an EMUparticipating Member State, despite their withdrawal from the EU, explain the involvement of the competent authorities of the French Republic in negotiating, with the EU, a Monetary Agreement for Saint Barthélemy, and their continuing role, subsequent to that agreement's entry into force, in monitoring compliance with its terms and provisions. The continuing use of the single currency in the island of Saint Barthélemy was, therefore, the result of a mutual agreement, rather than the automatic consequence of its transformation into an OCT, despite the uninterrupted use in its territory, since 1 January 2002, of the single currency.

\section{Euro adoption procedure and implications \\ (i) Introductory remarks}

One of the recurring questions in the public debate surrounding the issue of secession is whether a newly created state entity would be under a legal obligation to formally adopt the single currency after joining the EU. For the reasons set out in this subsection, it is submitted that this question is to be answered in the affirmative.

With the exception of a handful of EU Member States that enjoy the benefit of a specific, Treaty-based derogation (popularly referred to as an 'opt-out'), ${ }^{185}$ all remaining EU Member States are under an implicit, non-time-bound legal obligation $^{186}$ to accede to the third stage of EMU (i.e. adopt the single currency) upon fulfilment of the applicable criteria (see below). Until such time as they have fulfilled those criteria and been admitted to the euro area, EU Member States are to be treated as 'Member States with a (temporary) derogation', within the meaning of Article 139 TFEU. The temporary (and transitional) nature of derogations from the third stage of EMU and, indirectly, the mandatory character of EMU accession are abundantly clear in the text of Article 141 TFEU. ${ }^{187}$

185 The only EU Member States benefiting from a Treaty-based opt-out from EMU are Denmark and the UK. Both Member States secured derogations at the time of the negotiation of the Maastricht Treaty (see Protocol 15, for the UK, and Protocols 16-17, for Denmark, annexed to the TFEU). 186 This obligation is derived from Articles 140(1) and 140(2) TFEU, which point to the commitment of non EMU-participating Member States to maintain momentum towards the abrogation of their derogations and their eventual transition to the single currency.

187 This inter alia provides that 'If and as long as there are Member States with a derogation [emphasis added] ... the General Council of the European Central Bank referred to in Art. 44 of the Statute of the ESCB and of the ECB shall be constituted as a third decision-making body of the European Central Bank' and that, 'If and as long as there are Member States with a derogation [emphasis added], the European Central Bank shall, as regards those Member States' assume a number of coordination and cooperation tasks. 
They are also reflected in the EU Commission's consistent practice of discouraging the holding of national referenda for the adoption of the single currency. ${ }^{188}$

Although euro membership is obligatory, it is not automatic for those Member States that do not fulfil the accession criteria. Moreover, despite positing accession to the euro area as the 'final destination' for all EU Member States (except for those with a Treaty-based opt-out) the Treaties do not specify an exact timeframe for the adoption, by an EU Member State, of the single currency. Besides, one of the mandatory requirements for joining the euro area and, at the same time, one of the key elements for setting the target date for euro adoption namely, a two year membership of the European Exchange Rate Mechanism (ERM-II) is voluntary, even if only in terms of the choice of the moment for a Member State to apply for such membership. The above observations do not detract from the legally obligatory character of EMU accession for all EU Member States, save for those with a Treaty-based opt-out: they merely point to the leeway that Member States have in terms of their choice of the target date for euro adoption. ${ }^{189}$ It is telling of the EU Member States' perception of EMU accession as a legal obligation deriving from their EU membership that of the 10 countries that joined the EU in 2004, six had already acceded, at the time of writing, to the euro area, with another two planning to join in the foreseeable future. ${ }^{190}$ The remainder were at least reflecting on the issue of euro adoption, however much espousing a 'wait and see' approach. In the same vein, both of the 2007 EU Enlargement Member States had plans to adopt the single currency by 2017, despite delays and postponements, attributable, in part, to the on-set of the European sovereign debt crisis. ${ }^{191}$

While it is, in theory, conceivable that acceding Member States could negotiate permanent opt-outs with their EU partners, recorded in the relevant Accession Treaties, it is by no means a foregone conclusion that they will achieve what only few others before them have achieved: their negotiated exemption from the Monetary Policy Chapter of the Treaty, with the seal of approval of the

188 The EU Commission has discouraged the holding of referenda for the adoption of the euro, except in the case of Member States which have either secured opt-outs (Denmark) or where the possibility of referenda has been explicitly recognized by all parties, even absent a formal opt-out (Sweden). The rationale of the Commission's stance is that, by deciding to join the EU, Member States have assumed the obligation to also join (at a later stage) the euro area. Because the issue of euro area membership has already been decided as part of the EU membership package, it cannot be reopened.

${ }^{189}$ The sui generis example of Sweden (which, while not having formally negotiated an opt-out, as it only joined the EU in 1995, after the Maastricht Treaty was signed, has not joined ERM II and wilfully avoids meeting the convergence criteria on technical issues, relative to the legislation governing its NCB) suggests that Member States, including those without an opt-out, have considerable room for manoeuvre in terms of when they are to actually adopt the single currency.

${ }^{190}$ Lithuania was expected to adopt the euro in 2015. At the time of publication, Latvia was the last EU Member State to have adopted the euro (1 January 2014).

191 The reference is to Romania and Bulgaria, whose original tentative euro adoption target dates of 2015 and 2014 respectively have been postponed. 
European Council. Indeed, the prevailing view is that no new derogations from EMU are conceivable going forward: the window of opportunity for any such derogations closed at the time of the Maastricht Treaty-related negotiations, with no fresh derogations from EMU being possible anymore. EMU accession has, in other words, become part of the Union acquis for all new EU Member States. ${ }^{192}$ Besides, it is unlikely, to say the least, whether state entities resulting from secession from a Member State with an opt-out would 'inherit', as a matter of PIL, the rump Member State's opt-out: for the reasons explained in Part I, state succession would only be possible in a case of dissolution of a Member State, but not in a case of secession. The prospect of euro area membership, however distant in time, is, therefore, in the authors' view, inescapable, and it is as such that it should be portrayed in the public debate surrounding secession.

With the above considerations in mind, the following paragraphs provide an outline of the EMU accession procedure, followed by an account of some of the principal institutional and financial implications of EMU participation for new Member States (including those resulting from secession) and their NCBs.

\section{(ii) EMU accession procedure: an outline}

Except in the case of Member States with a Treaty-based opt-out, accession to EMU is mandatory for all EU Member States, not only as an outcome (see Part I, Section A(iii)) but, also, in terms of procedure: candidates need to fulfil certain prescribed 'convergence criteria', including currency convergence as part of ERM-II, and follow a pre-determined, 'institutional' path to accession before adopting the single currency.

The EMU accession procedure involves three distinct (but inter-related) consecutive stages, of which the first is formal accession to the EU. ${ }^{193}$ The second stage is a Member State's participation, for a minimum of two years, in ERM-II: ${ }^{194}$ this involves the setting of a central parity and the observance of the currency fluctuation bands by the EMU candidate Member State, without substantial fluctuations throughout the two-year reference period. The third and final stage involves an assessment, by the Commission and the ECB, of the EMU candidate Member State's fulfilment of the economic and legal convergence criteria (see the following paragraphs). The former are designed to ensure that the economy of a new euro area Member State is sufficiently prepared for its integration to the monetary regime backing the single currency, while the latter

\footnotetext{
192 Buiter and Grafe (n 171) 112-13.

193 As explained earlier, EU membership is, legally, a sine qua non condition for the adoption of the single currency, in the genuine sense of the term (that of formal EMU membership).

194 ERM II was established by virtue of a Resolution of the European Council of 16 June 1997 (OJ C 236, 2 August 1997, 5-6) as a multilateral arrangement of fixed, but adjustable, exchange rates with a central rate and a standard fluctuation band of $\pm 15 \%$, the aim of which is to link the currencies of non-euro area Member States to the euro. Within the framework of ERM II, exchange rate stability is explicitly subordinated to the primary objective of price stability for all participating currencies.
} 
are geared towards ensuring that national legislation is compatible with the Treaty and the Statute of the European System of Central Banks and of the European Central Bank (the Statute). ${ }^{195}$

Starting with the economic convergence criteria (popularly referred to as the 'Maastricht criteria', agreed by Member States in 1991, at the time of the preparations for the creation of the single currency), these are formally defined in Article 140(1) TFEU as a set of macroeconomic indicators measuring price stability (to demonstrate that inflation is under control), the soundness and sustainability of public finances (to avert excessive deficits), exchange-rate stability for a continued period of at least two years, without significant deviations from the ERM-II central rate (to demonstrate that a Member State can manage its economy without recourse to excessive currency fluctuations), ${ }^{196}$ and longterm interest rate stability (to help assess the durability of the convergence achieved by fulfilling the above criteria). To meet the economic convergence criteria, Member States need to display sustained fiscal and budgetary discipline. The proclaimed automaticity of EMU accession is apt to gloss over the degree of collective effort, commitment, and perseverance required to meet the economic convergence criteria, downplaying the cost of EMU accession and the future risks for an acceding country if its EMU accession is achieved in a non-durable, short-lived, or otherwise unsustainable manner. ${ }^{197}$

Apart from fulfilling the economic convergence criteria, candidates for accession to the euro area will also need to amend (in some cases more fundamentally than in others) their national legal frameworks, in line with the Treaty and the Statute, with an emphasis on the rules governing the organization and operation of their NCBs. The necessary legal adjustments seek to guarantee, in particular, their smooth integration in the Eurosystem as well as central bank independence as a condition precedent to the design and implementation of a credible monetary policy, free of the vagaries of national political processes and without regard to electoral cycles. ${ }^{198}$ Significantly, compliance with the Treaty and the Statute are on-going (rather than point-in-time) duties of acceding Member States, which are not exhausted at the time of their accession to EMU. Compliance with the Treaty and the Statute are inter alia monitored through the ECB's advisory role, touched on later in this section. The implications of the

195 The Statute is appended as Protocol No. 4 to the TFEU, and forms an integral part thereof.

196 The exchange rate criterion also provides an indication of the appropriate conversion rate that should be applied when a Member State qualifies and its currency is irrevocably fixed.

197 The European sovereign financial crisis provides ample illustrations of the implications of Member States achieving nominal economic convergence in an unsustainable manner.

198 There is a wealth of empirical research on the benefits of central bank independence. See, for instance, A Alesina and LH Summers, 'Central Bank Independence and Macroeconomic Performance' (1993) 25 Journal of Money, Credit and Banking 151; O Issing, 'Central Bank Independence-Economic and Political Dimensions' (2006) 1 National Institute Economic Review 66; F Papadia and Ruggiero, 'Central Bank Independence and Budget Constraints for a Stable Euro' [1999] Open Economies Review 63; R Smits, The European Central Bank_Institutional Aspects (Kluwer, The Netherlands 1997), 154ff. 
legal adjustments required for EMU accession (and the continuing duty to consult the ECB on all draft legislative provisions within its fields of competencesee the next paragraph) should not be underestimated, nor downplayed, in the public debate surrounding secession if misconceptions are to be avoided, and if false expectations of a one-off accession effort, terminating on the day of the adoption of the single currency, are not to be aroused.

Turning briefly to the assessment of compliance with the convergence criteria, it follows from Article 140(1)-(3) TFEU that at least once every two years, or at the request of a Member State with a (temporary) derogation, the Commission and the ECB are to assess the progress made by the euro-area candidate countries and publish their conclusions in their respective Convergence Reports. After consulting the European Parliament and after discussion in the European Council, the Council shall, on a proposal from the Commission, decide which Member States with a derogation fulfil the necessary EMU accession conditions, and abrogate their derogations. The Council shall act having received a recommendation of a qualified majority ${ }^{199}$ of those among its members representing Member States whose currency is the euro. These members shall act within six months of the Council receiving the Commission's proposal. If it is decided to abrogate a derogation, the Council shall, acting with the unanimity of the Member States whose currency is the euro and the Member State concerned, on a proposal from the Commission and after consulting the $\mathrm{ECB}$, irrevocably fix the rate at which the euro shall be substituted for the currency of the Member State concerned, and take all other measures necessary for the introduction of the euro in the Member State concerned. At the time of writing, Latvia was the EU Member State to have most recently joined the euro (January 2014), following the institutional path prescribed in the Treaty, with its neighbouring Lithuania preparing to adopt the single currency on 1 January 2015. Others are expected to follow in their steps in the next five years.

\section{(iii) Implications of EMU participation}

Accession to the euro area entails a permanent limitation of a Member State's sovereignty in the field of monetary and exchange rate policy, which, for participating Member States (defined as those whose currency is the euro), are exclusive EU competences, ${ }^{200}$ exercised, in full independence, ${ }^{201}$ and for the benefit of the entire euro area, by the decision-making bodies of the ECB, the euro area's single monetary authority. Whilst the Governor of the NCB of an acceding euro area Member State will sit, ex officio, at the Governing Council (the ECB's supreme

\footnotetext{
199 The qualified majority of the said members, as referred to in the second subparagraph, shall be defined in accordance with Art. 238(3)(a)TFEU.

200 See Art. 3(1) (c) TFEU.

201 Central bank independence, enshrined in Art. 130 TFEU and Art. 7 of the Statute, is central to the philosophy and modus operandi of the ESCB, and to its pursuit of price stability as its primary objective, in line with Art. 127 TFEU.
} 
decision-making body), contributing to the design of the single monetary policy on an equal footing with all other Governing Council Members, ${ }^{202}$ the task of her home NCB will be to implement the monetary policy decisions of the Governing Council (as opposed to independently deciding on matters of monetary policy), in line with the Statute, its national implementation of the General Documentation, ${ }^{203}$ and the principle of 'decentralization of operations'. ${ }^{204}$ It is worth recalling here that, as regards the performance of their ESCB tasks, ${ }^{205} \mathrm{NCB}$ Governors are neither national officials nor national representatives, but supranational experts in banking matters, and ad personam members of the Governing Council, each with one, equally weighted vote: to assume that they will represent, post-accession, national interests, while sitting at the Governing Council, is to misunderstand their role, the hierarchical position of the ECB and the NCBs within the Eurosystem and the aims of the ESCB. 206

On the irrevocability of the adoption of the single currency, hinted to above - and, by extension, on the lasting nature of the commitments associated with its adoption - suffice it to point to Article 3 TEU, 207 as well as to Article 140(3) TFEU, and Protocol 24 to the Treaty of Maastricht on the Member States' transition to the third stage of EMU. ${ }^{208}$ By expressly referring to the

202 The only exception to the 'one man one vote' rule applicable to the deliberations of the Governing Council is where patrimonial issues are concerned (ie issues relating to the ECB's capital or to the transfer of foreign reserves or to the allocation of profits and losses within the ESCB), where the NCB Governors' votes are weighted to reflect the share of each NCB in the ECB's capital, as per Art. 10.3 of the Statute.

203 The reference is to Guideline ECB 2011/14 of 20 September 2011 on monetary policy instruments and procedures of the Eurosystem (recast), OJ L 331, 14 December 2011, 1, the euro area's common 'rule book' for the conduct of monetary policy operations. Whilst the last four years-in other words the period broadly spanning the time between the onset of the financial crisis and its dénouement-have witnessed a gradual but appreciable shift towards more discretion in the participating NCBs' implementation of the single monetary policy, the Eurosystem's approach to monetary policy implementation remains overwhelmingly rule-based.

204 The reference is to the Eurosystem's key operational principle whereby, to the extent possible, the ECB shall have recourse to NCBs to carry out operations which form part of the tasks of the Eurosystem. In order to ensure that decentralization does not hamper the smooth functioning of the Eurosystem, NCBs have to act in accordance with ECB Guidelines and Instructions, as the ECB's 'operating arms'. Where operations can be carried out more effectively if directly handled by the $\mathrm{ECB}$, the ECB will instead act in a centralized manner. It is noted that the principle of decentralization applies to operations only, while decision-making and legislation remain centralized.

205 The ESCB tasks are defined in Art. 127(2) TFEU and in Art. 3 of the Statute.

206 The point is not uncontested: some consider the NCB Governors as (predominantly) national officials, representing their home institutions when sitting in the ECB Governing Council (see, for instance, P Stanek, 'How to Assess Proposals for Enlargement Reform of The European Central Bank' (2004) 91(5) Revue de l'OFCE, Presses de Sciences-Po, 209-39, 228). For an in-depth assessment of this issue see P Athanassiou, 'Reflections on the Modalities for the Appointment of the National Central Bank Governors' (2014) 39 European Law Review, 27-47.

207 It follows from this provision that the establishment of 'an economic and monetary union whose currency is the euro' is among the list of objectives of the EU.

${ }^{208}$ Member States inter alia declared 'the irreversible character of the Community's movement to the third stage of EMU', inter alia stating that all preparatory work should be concluded by 1998 'in order to enable the Community to enter into the third stage irrevocably on 1 January 1999'. 
establishment of EMU as an EU objective and to the 'irrevocable' fixing of the conversion rates at which national currencies are to be exchanged for the euro, the foregoing provisions draw attention to the irreversibility of the process leading to a Member State's adoption of the single currency and, thereafter, to its lasting character. ${ }^{209}$ It is also for that reason that to extrapolate, as some have, from the recently introduced Article $50 \mathrm{TEU}$, anything akin to a unilateral right of withdrawal from EMU (without a parallel withdrawal from the EU), is legally flawed. ${ }^{210}$ EMU is no 'revolving door' through which participating Member States can enter or exit, at will, their EU membership-derived rights and obligations as members of the monetary union. The irreversibility of the EMU accession process and the permanence of the commitments it comes with are legal realities that new state entities (including those resulting from secession) willing to accede to the EU would need to appreciate and accept. ${ }^{211}$

What is also worth drawing attention to is that the permanent limitation, referred to at the start of this subscetion, in the decision-making autonomy of a participating Member State (or its monetary policy authority) consequent on EMU accession extends beyond the field of monetary policy. More specifically, whilst recognizing that the NCBs 'may perform functions other than those specified in this Statute', Article 14.4 of the Statute allows the Governing Council to object, by a two-thirds majority, to any non-ESCB operations carried out by a participating Member State NCB (including ELA, foreign reserves asset management, or own investment operations), which the Governing Council deems to interfere with the implementation of the single monetary policy. The effet utile of Article 14.4 of the ESCB Statute would, in principle, permit the Governing Council to impose whatever conditions it deems fit before exercising its (negative) discretion not to object to an operation that a participating Member State NCB proposes to undertake. Besides, it follows from Article 127(4) TFEU and Article 4 of the Statute that the legislative bodies of the Member States are required to consult the ECB in respect of any draft national legislative provisions falling within the ECB's field of competence. The ECB's advisory role is inter alia intended to ensure that no national legal act falling within its field of competence is adopted without its prior consultation. ${ }^{212}$

209 See C Zilioli and M Selmayr, The Law of the European Central Bank (Hart, Oxford, 2001) 15; C Proctor, 'The Future of the Euro-What Happens if a Member State Leaves?' (2006) 17 European Business Law Review 909, 924-5; and Athanassiou (n 2) 13-14.

${ }^{210}$ In this regard see, generally, Athanassiou (n 2) fn.1; and <https://www.ecb.int/pub/pdf/other/ 20121107_morganti.en.pdf > last accessed on 31 August 2013. The reason why the Treaty of Lisbon does not provide for the possibility of withdrawing from EMU without a parallel withdrawal from the EU is precisely because of the irreversibility of the transition to the third stage of EMU.

211 On the irrevocability of the transfer of monetary policy competences to the ECB, see C Zilioli, 'National Emergency Powers and Exclusive Community Competences-A Crack in the Dam?' in Legal Aspects of the European System of Central Banks (Liber Amicorum Paolo Zamboni Garavelli) (European Central Bank, 2005) 115-33.

${ }^{212}$ For an account of the legal parameters of the ECB's advisory tasks see, generally, A Arda, 'Consulting the European Central Bank-Legal Aspects of the Community and National 
The procedural aspects of the ECB's advisory role are set out in Council Decision 98/415/EC on the ECB's consultation by national authorities regarding draft legislative provisions, ${ }^{213}$ which is drafted in general terms and applies to all EU Member States (whether or not they have acceded to EMU). ${ }^{214}$ A failure to consult the ECB on a draft national legislative provision within its fields of competence could lead to infringement proceedings before the CJEU, brought by the European Commission against the Member State concerned, in accordance with Article 258 TFEU. ${ }^{215}$ The duty of consultation under the Decision is precise and unconditional, which means that individuals can rely upon it before national courts. To date, national courts have not been asked to rule on the validity or enforceability of a national provision adopted without a prior consultation of the $\mathrm{ECB}$, and no request for a preliminary ruling in this matter has so far been addressed to the CJEU. However, the CJEU has repeatedly ruled on the enforceability of national provisions adopted without prior notification to the European Commission, as required by certain EU legal acts, and has held that such provisions are unenforceable against individuals if adopted in breach of substantial procedural requirements. ${ }^{216}$

Apart from the aforementioned lasting, institutional implications of the adoption of the single currency, accession to the euro area also entails certain financial obligations for acceding Member States or their NCBs. The magnitude of these obligations has increased considerably in recent years, on account of the joint euro area efforts to stem the sustained European sovereign debt crisis, to address the acute financial and economic difficulties experienced by a number of EMU Member States and to prevent contagion. Starting with the non-crisis-related costs of accession to EMU, the NCBs of participating Member States are to first contribute, as shareholders, to the capital of the ECB, in accordance with the ECB's 'capital subscription key'; 217 second, they are to transfer foreign reserve

Authorities' Obligation to Consult the ECB Pursuant to Art. 105(4) EC', (2004) 1 European Banking and Financial Law Journal (Euredia) 111-52.

213 OJ L 189, 3 July 1998, 42-3.

214 The notable exception is that of the UK, which is exempt from the obligation to consult the ECB under the terms of paras 4 and 7 of Protocol 15 on certain provisions relating to the United Kingdom of Great Britain and Northern Ireland, annexed to the Treaty (also see Recital 7 of Council Decision 98/415/EC).

215 If an NCB endowed with regulatory powers fails to consult the ECB, the ECB can itself commence infringement proceedings under Art. 271(d) TFEU and Art. 35.6 of the Statute, which acknowledge the jurisdiction of the CJEU in disputes concerning the fulfilment by NCBs of obligations under the Treaty and the ESCB Statute.

216 See, inter alia: Case 174/84, Bulk Oil [1986] ECR 559; Case 380/87, Enichem Base [1989] ECR 2491; Case C-194/94, CIA Security International [1996] ECR I-2201; Case C-226/97, Lemmens [1998] ECR I-3711; Case C-235/95, AGS Assedic Pas-de-Calais [1998] ECR I-4531; Case C-443/ 98, Unilever [2000] ECR I-7535; Case C-159/00, Sapod Audic [2002] I-5031.

217 The NCBs' shares in the capital of the ECB are calculated using a key reflecting their respective share in the total population and gross domestic product of the EU. These two determinants have equal weighting. The ECB adjusts the shares every five years and whenever a new country joins the EU. 
assets to the ECB, in accordance with Article 30 of the Statute, ${ }^{218}$ and third they are to share in the ECB's net losses (and, reciprocally, in its net profits). ${ }^{219}$ No less importantly, EMU-acceding Member States are under an obligation to contribute to the subscribed capital of the European Stability Mechanism (ESM), a permanent Treaty-based intergovernmental organization ${ }^{220}$ tasked $^{2}$ with assisting in preserving financial stability by providing temporary financial assistance to troubled euro area Member States. ${ }^{221}$ Participating Member States had previously been involved in funding the European Financial Stability Facility (EFSF), the ESM's precursor (which, unlike the ESM, obtained financing by issuing bonds or other debt instruments on the financial markets, based on guarantees for its liabilities provided by the euro area Member States). ${ }^{222}$ While all contributing Member States are potential beneficiaries of the unprecedented safety net provided through the establishment of the EFSF-ESM, the cost implications of their establishment can be significant for existing and EMU-acceding Member States alike. Overall, the public expenditure required to meet the financial obligations and liabilities outlined above (including the non-crisis-related ones) will need to be factored into any comprehensive assessment of the economic costs and benefits of secession, becoming part of the political narrative of the merits and rationale of secession.

218 The Statute distinguishes between official 'foreign reserve assets' (which include gold and other precious metals) transferred to the ECB, in line with Art. 30 of the Statute, and those held and managed by the participating Member State NCBs. The Statute imposes certain restrictions in connection with transactions over 'foreign reserve assets' held and managed by the participating Member State NCBs. In particular, Art. 31.2 of the Statute provides for the approval of the Governing Council in case of foreign reserve asset operations above a certain threshold established by the Governing Council in order to ensure consistency with the exchange rate and monetary policies of the Union.' Even Member States' transactions with their 'foreign exchange working balances', above a certain threshold, are subject to such approval from the ECB (see Guideline ECB/2003/12 of 23 October 2003 for participating Member States' transactions with their foreign exchange working balances pursuant to Art. 31.3 of the Statute of the European System of Central Banks and of the European Central Bank, OJ L 283/81, 31 October 2003; Zilioli and Selmayr (n 209), 102; and R Smits, The European Central Bank-Institutional Aspects (Kluwer, The Netherlands 1998) 199-201).

219 The net profits and losses of the ECB are allocated among the euro area NCBs in accordance with Art. 33 of the Statute. As the balance sheet of the ECB has expanded considerably since the start of the European sovereign debt crisis, if they were to ever materialize, losses could, be substantial. These losses would, ultimately, be borne by the NCB's home Member States, as there is an implicit Treaty-based duty for Member States to replenish the capital of their NCBs in the event of losses, in the interests of preserving their financial independence.

220 The Treaty Establishing the European Stability Mechanism was signed on 2 February 2012, establishing the ESM. The ESM was finally inaugurated on 8 October 2012 upon completion of the ratification process by the euro area Member States.

221 The ESM will have total subscribed capital of $€ 700$ billion provided by euro area Member States; $€ 80$ billion of this will be in the form of paid-in capital with the remaining $€ 620$ billion as callable capital.

222 The EFSF was established on 7 June 2010 as a Luxembourgish law société anonyme, mandated to provide financial assistance on a temporary basis. The EFSF will continue to service existing commitments even after 30 June 2013, the date of its substitution by the ESM. 
In short, and without prejudice to the unquestionable long-term political, strategic, structural, and financial benefits of EMU participation, ${ }^{223}$ EMU accession entails a handful of momentous institutional and financial consequences, which the decade of prosperity and macroeconomic stability preceding the onset of the financial crisis had somewhat obfuscated or whose import it had blurred. ${ }^{224}$ The establishment of a Single Supervisory Mechanism is set to signal a further highly significant, medium- to short-term institutional shift, this time in terms of supervisory responsibility over (some of the) credit institutions operating within the EU (and, especially, EMU): following an agreement reached by the Eurogroup on 13 December 2012, and the adoption of the SSM Regulation, ${ }^{225}$ banking supervision is to be transferred from the competent national supervisory authorities to the $\mathrm{ECB},{ }^{226}$ as a first step towards a genuine banking union, also involving, at a later stage, a single resolution authority, a common resolution fund and a single deposit guarantee scheme. In the longer term, just as the single currency has been the logical culmination of the single market, EMU participation could usher in fiscal and, perhaps, also political union.

A final remark is apposite on the impact of the on-going European sovereign debt crisis, already in its fourth year at the time of writing. The crisis has brought to the fore the advantages inherent in a Member State's participation in a monetary policy model of which the euro area is a unique and unprecedented example, in terms of organized solidarity, but also its strictures. One of the bitter lessons of the European sovereign debt crisis is that euro area membership presupposes a lasting commitment on the part of all participating Member States to observe, unswervingly, the 'rules of the game', laid down in the Stability and Growth Pact, ${ }^{227}$ by inter alia avoiding excessive deficits, constantly improving on their competitiveness and steering clear of labour market

223 These include increased price stability, deeper financial markets with lower financial transaction costs, thanks to the suppression of multiple European exchange rates, enhanced competition for goods and services and financial support at times of crisis).

${ }_{224}$ These include loss of monetary policy and exchange rate-setting autonomy, conversion of the $\mathrm{NCB}$ of a participating Member State from a purely national instance into an operational arm of the ECB, financial contribution to the ECB's share capital and to any losses it may incur, transfer to the ECB of foreign reserve assets, loss of autonomy in terms of the Member States' use of their nontransferred foreign reserve assets, and, last but not least, contribution to the capital of the ESM.

225 Council Regulation (EU) No 1024/2013 of 15 October 2013 conferring specific tasks on the European Central Bank concerning policies relating to the prudential supervision of credit institutions, OJ L 287, 29 October 2013, 63.

226 The proposed transfer is all the more important considering that, in the case of EMU participating Member State NCBs, banking supervision is their most important non-ESCB-related task.

227 The Stability and Growth Pact, as amended over time, aims at safeguarding macroeconomic stability in the euro area. It focuses, in particular, on the maintenance of fiscal discipline through enhanced surveillance of the fiscal positions of EMU participants. In particular, under the Pact, each EMU participant should aim at a medium-term position that is at least close to balance so that in the face of normal cyclical fluctuations there would be a sufficient margin of safety to avoid deficits in excess of $3 \%$ of GDP. Unless a general government deficit in excess of the 3\% cent ceiling is deemed exceptional and temporary, the Council of Ministers can impose financial sanctions based on a 
rigidities, since their margin of manoeuvre is bound to be narrower, at times of crisis, compared to that of outsiders. The political establishments in seceding state entities will need to internalize this lesson, and prepare their public opinions for the lasting fiscal and budgetary discipline necessary for them to reap the full benefits of euro area participation (as well as for its medium- and longerterm implications, briefly drawn attention to above). Positing as automatic the accession of a new state entity to EMU does not appear likely to help instil that discipline, nor is it likely to contribute towards familiarizing public opinion in a newly created state entity with the concrete consequences of and obligations deriving from EMU accession.

\section{Concluding remarks}

The aim of this paper has been to make a modest but informed contribution to the debate regarding secession and its consequences for EU membership. Having examined in Part I the issue of secession, from an EU and a PIL law perspective, we have come to the conclusion that there is no automatic right to EU accession, and no right of succession for a newly created state entity. EU membership talks would, in the authors' opinion, be mandatory both in terms of outcome (through the enlargement process) and in terms of procedure (through the enlargement criteria), even if it may be possible for the accession procedure to be simplified or expedited, subject to negotiations, because a newly created state entity resulting from secession may be better able to satisfy the admission requirements compared to a genuine novice. However significant their impact on the debate, arguments drawn from the protection of fundamental rights and, in particular, from the notion of EU Citizenship would appear to do little to change that conclusion.

Part II has drawn attention to the concrete consequences of EMU accession for new Member States (including state entities resulting from secession). Although participation to EMU is mandatory for all EU Member States, it does not derive automatically from EU membership, being instead subject to conditionality outside the enlargement process. Starting from the premise that the Treaty is silent on the possibility of an internal EMU enlargement, it has been argued that, unless the Treaty were to be amended, state entities created through secession from EMU-participating Member States would have to follow the same path to EMU accession as their precursors, despite having formerly been part of an EMU-participating Member State. The legally obligatory character of EMU accession, as a contractual obligation derived from EU membership, has also been drawn attention to. 
One final remark is apposite on the implications of the crisis-driven process of European integration for the secession debate. The gradual pooling of sovereignty among EU and EMU Member States over so broad a range of core issues (from monetary policy and banking supervision to fiscal competences, bank resolution and deposit insurance) accelerated by the sovereign debt crisis may, perhaps, call into question the rationale and practical impact of secession, casting it in the light of an oddity, at a time of ever closer EU and EMU convergence. Given their import, the institutional, legal, economic, and budgetary consequences of EU and EMU accession, including future changes towards further transfers of sovereignty on account of the fallout of the European sovereign debt crisis, would need to be explained to and understood by public opinion in any of the Member States where secession is on the table. Without clarity and transparency on the issues touched on above there is a risk of decisions being taken the practical consequences of which have not been exhaustively thought through despite the existence of readily available legal tools through which to come to the right conclusions. 